Prepared in cooperation with the National Park Service

Estimates of Future Inundation of Salt Marshes in Response to Sea-Level Rise in and Around Acadia National Park, Maine

Scientific Investigations Report 2012-5290 
Cover. View of salt marsh (looking east) on Great Cranberry Island. Photograph taken by Robert Dudley. 


\section{Estimates of Future Inundation of Salt Marshes in Response to Sea-Level Rise in and Around Acadia National Park, Maine}

By Martha G. Nielsen and Robert W. Dudley

Prepared in cooperation with the National Park Service

Scientific Investigations Report 2012-5290 


\section{U.S. Department of the Interior \\ KEN SALAZAR, Secretary}

\section{U.S. Geological Survey \\ Suzette M. Kimball, Acting Director}

U.S. Geological Survey, Reston, Virginia: 2013

For more information on the USGS - the Federal source for science about the Earth, its natural and living resources, natural hazards, and the environment, visit http://www.usgs.gov or call 1-888-ASK-USGS.

For an overview of USGS information products, including maps, imagery, and publications, visit http://www.usgs.gov/pubprod

To order this and other USGS information products, visit http://store.usgs.gov

Any use of trade, firm, or product names is for descriptive purposes only and does not imply endorsement by the U.S. Government.

Although this information product, for the most part, is in the public domain, it also may contain copyrighted materials as noted in the text. Permission to reproduce copyrighted items must be secured from the copyright owner.

Suggested citation:

Nielsen, M.G., and Dudley, R.W., 2013, Estimates of future inundation of salt marshes in response to sea-level rise in and around Acadia National Park, Maine: U.S. Geological Survey Scientific Investigations Report 2012-5290, 20 p., http://pubs.usgs.gov/sir/2012/5290/. 


\section{Acknowledgements}

This study was funded through the National Park Service Natural Resource Stewardship and Science Climate Change Response Program. The authors thank the staff at Acadia National Park, The Nature Conservancy, and especially the Maine Coast Heritage Trust for their assistance in obtaining permissions for access to privately held salt marshes for the surveying phase of the project. We also thank the numerous private landowners who allowed access to their property. Luke P. Sturtevant of the U.S. Geological Survey, Maine Water Science Center, provided valuable assistance with the mapping and geodatabase. National Park Service staff who reviewed the initial proposal provided very helpful suggestions for the project. 
This page has been left blank intentionally. 


\section{Contents}

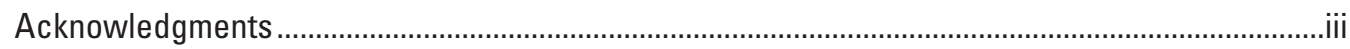

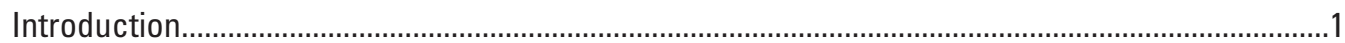

Coastal Inundation from Sea-level Rise and Migration of Salt Marshes .................................2

Approaches and Datum Characteristics for Assessing Potential Effects of Inundation..........4

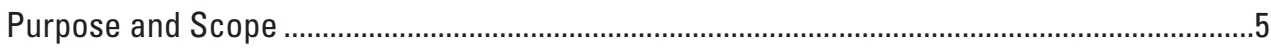

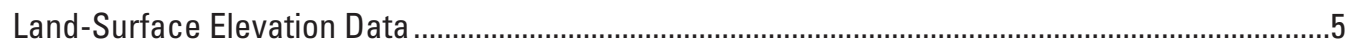

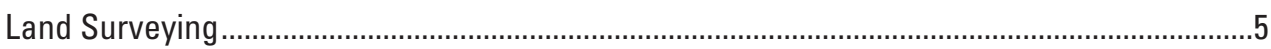

Vertical Accuracy Assessment for Land-Surface Elevation Data...........................................

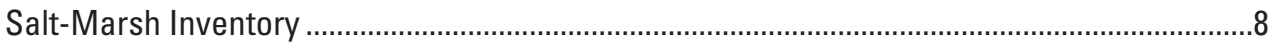

Estimated Future Inundation Resulting from Sea-Level Rise at Salt Marshes................................9

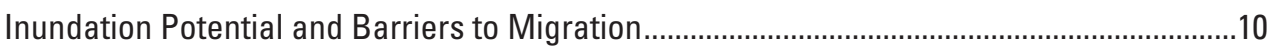

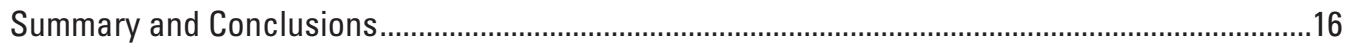

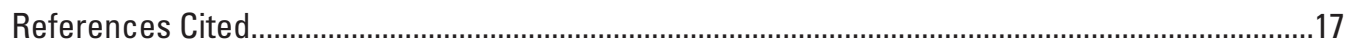

Appendix 1. Geospatial data of salt marshes, inundation contours, and surveying data in and near Acadia National Park, Maine. ........................................................................19

\section{Figures}

1. Photograph showing Mitchell Marsh near Bass Harbor, Maine.......................................2

2. Map showing location of study area in and around Acadia National Park, Maine ..........3

3. Photographs showing $A$, a lag bolt anchored in bedrock that serves as an elevation reference mark, $B$, a global-positioning system (GPS) receiver placed on an elevation reference mark, and C, a wooden stake flush with the marsh surface that serves as a control point ....................................................................................................

4. Graph showing cumulative distribution of salt marsh areas, in hectares ........................9

5. Map showing the distribution of salt marshes within the coastal towns in the study area

6. Diagram showing relation of local elevation datum to the inundation contours, 95-percent confidence interval contours, and the inundation uncertainty zone for salt marshes in the study area

7. Histogram showing the estimated area of upland adjacent to salt marshes that will be inundated with 60 centimeters of sea-level rise, shown as a percentage of adjacent salt marsh area.

8. Histogram showing the average distance of the 60 -centimeter inundation contours inland from salt marsh edges

9. Static inundation map for 60 centimeters $(\mathrm{cm})$ of sea-level rise and upper and lower 95-percent confidence interval contours for the Somesville area, Mount Desert, Maine, using A, shaded relief image of light detection and ranging (LiDAR) data and B, orthophoto base

10. Static inundation map for 60 centimeters $(\mathrm{cm})$ of sea-level rise and upper and lower 95-percent confidence interval contours for the Northeast Creek area, Bar Harbor, Maine, using $A$, shaded relief image of light detection and ranging (LiDAR) data and $B$, orthophoto base

11. Static inundation map showing potential barriers to marsh migration for the Thomas

Bay area, Bar Harbor, Maine 


\section{Tables}

1. Inventory of salt marshes in towns within the study area, including number of marshes and total marsh areas for areas with Acadia National Park ..............................9

2. Inventory of potential barriers to marsh migration in towns within the study area ........16

\section{Conversion Factors and Datum}

\begin{tabular}{llll}
\hline \multicolumn{1}{c}{ Multiply } & By & & To obtain \\
\hline & Length & & \\
\hline centimeter $(\mathrm{cm})$ & 0.3937 & inch (in.) & \\
millimeter (mm) & 0.03937 & inch (in.) & \\
meter (m) & 3.281 & foot (ft) & \\
kilometer (km) & 0.6214 & miles (mi) & \\
\hline & Area & \\
\hline hectare (ha) & 2.471 & acre \\
\hline
\end{tabular}

Vertical coordinate information is referenced to the North American Vertical Datum of 1988 (NAVD 88).

Horizontal coordinate information is referenced to the North American Datum of 1983 (NAD 83).

Elevation, as used in this report, refers to distance above the North American Vertical Datum (NAVD 88). 


\title{
Abbreviations
}

\author{
ALS Airborne laser surveying \\ ANP Acadia National Park \\ CO-OPS Center for Operational Oceanographic Products and Services \\ CORS Continuously operating reference stations \\ DEM digital elevation model \\ DSC Denver Service Center \\ ERM elevation reference mark \\ GPS global-positioning system \\ HAT highest astronomical tide \\ HME highest marsh elevation \\ LGO Leica GeoOffice \\ LiDAR light detection and ranging \\ MDI Mount Desert Island \\ MHW mean high water \\ MRSA Maine Revised Statutes Annotated \\ MSL mean sea level \\ NGS National Geodetic Survey \\ NMAS National Map Accuracy Standard \\ NOAA National Oceanic and Atmospheric Administration \\ NOS National Ocean Services \\ NPS National Park Service \\ NRPA Natural Resources Protection Act \\ NTDE National Tidal Datum Epoch \\ ODI ortho-rectified digital images \\ OPUS Online Positioning User Service \\ RMSE Root mean square errors \\ SLR Sea-level rise \\ TS Total Station \\ USGS U.S. Geological Survey \\ USEPA U.S. Environmental Protection Agency
}


This page has been left blank intentionally. 


\title{
Estimates of Future Inundation of Salt Marshes in Response to Sea-Level Rise in and Around Acadia National Park, Maine
}

\author{
By Martha G. Nielsen and Robert W. Dudley
}

\section{Abstract}

Salt marshes are ecosystems that provide many important ecological functions in the Gulf of Maine. The U.S. Geological Survey investigated salt marshes in and around Acadia National Park from Penobscot Bay to the Schoodic Peninsula to map the potential for landward migration of marshes using a static inundation model of a sea-level rise scenario of 60 centimeters ( $\mathrm{cm} ; 2$ feet). The resulting inundation contours can be used by resource managers to proactively adapt to sea-level rise by identifying and targeting low-lying coastal areas adjacent to salt marshes for conservation or further investigation, and to identify risks to infrastructure in the coastal zone. For this study, the mapping of static inundation was based on digital elevation models derived from light detection and ranging (LiDAR) topographic data collected in October 2010. Land-surveyed control points were used to evaluate the accuracy of the LiDAR data in the study area, yielding a root mean square error of $11.3 \mathrm{~cm}$. An independent accuracy assessment of the LiDAR data specific to salt-marsh land surfaces indicated a root mean square error of $13.3 \mathrm{~cm}$ and 95-percent confidence interval of $\pm 26.0 \mathrm{~cm}$. LiDAR-derived digital elevation models and digital color aerial photography, taken during low tide conditions in 2008, with a pixel resolution of 0.5 meters, were used to identify the highest elevation of the land surface at each salt marsh in the study area. Inundation contours for $60-\mathrm{cm}$ of sea-level rise were delineated above the highest marsh elevation for each marsh. Confidence interval contours (95-percent, $\pm 26.0 \mathrm{~cm}$ ) were delineated above and below the $60-\mathrm{cm}$ inundation contours, and artificial structures, such as roads and bridges, that may present barriers to salt-marsh migration were mapped.

This study delineated 114 salt marshes totaling 340 hectares (ha), ranging in size from 0.11 ha (marshes less than 0.2 ha were mapped only if they were on Acadia National Park property) to 52 ha, with a median size of 1.0 ha. Inundation contours were mapped at 110 salt marshes. Approximately 350 ha of low-lying upland areas adjacent to these marshes will be inundated with $60 \mathrm{~cm}$ of sea-level rise. Many of these areas are currently freshwater wetlands.
There are potential barriers to marsh migration at 27 of the 114 marshes. Although only 23 percent of the salt marshes in the study are on ANP property, about half of the upland areas that will be inundated are within ANP; most of the predicted inundated uplands (approximately $170 \mathrm{ha}$ ) include freshwater wetlands in the Northeast Creek and Bass Harbor Marsh areas. Most of the salt marshes analyzed do not have a significant amount of upland area available for migration. Seventy-five percent of the salt marshes have 20 meters or less of adjacent upland that would be inundated along most of their edges. All inundation contours, salt marsh locations, potential barriers, and survey data are stored in geospatial files for use in a geographic information system and are a part of this report.

\section{Introduction}

Salt marshes provide significant ecological value and aesthetic beauty to Maine's coasts (fig. 1). Their ecological functions include nursery and breeding habitat for many fish, migratory birds, and other wildlife species; organicmatter production that maintains coastal food webs for many commercially and recreationally valuable species; storm, flood, and erosion protection; carbon sequestration; and filtration of nutrients, sediments, and contaminants from waters entering the coastal zone. Salt marshes form and grow close to sea level under special conditions that provide intermittent exposure to saltwater and vertical development through the supply and accumulation of fine-grained mineral sediment and plant organic matter (Cahoon and others, 2009). As salt-marsh plants grow, their roots and rhizomes, along with sediment and organic matter, form peat - the foundation of the marsh.

A recent vegetation inventory of the Acadia National Park (ANP) and its associated lands (conservation easements) identified 47 salt-marsh areas on numerous islands and other parcels in and near ANP land holdings in the Gulf of Maine (Lubinski and others, 2003). Many additional salt marshes along the hundreds of kilometers of coastline exist within the area encompassed by the ANP vegetation survey (from eastern Penobscot Bay to the Schoodic Peninsula), but were not 


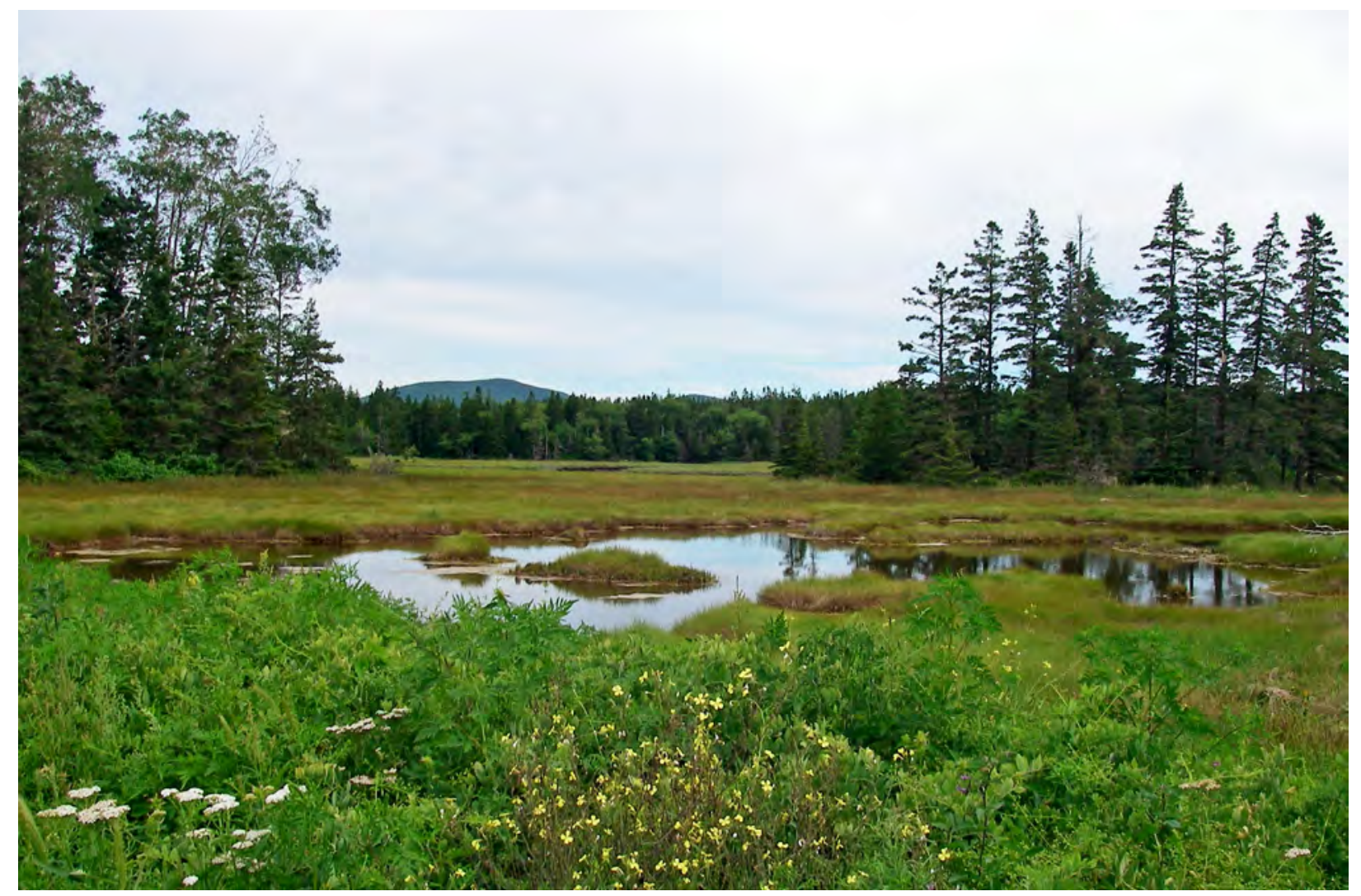

Figure 1. Mitchell Marsh near Bass Harbor, Maine.

mapped for that study. These salt marshes are highly valued for their wildlife viewing and aesthetic landscape, and are enjoyed by the 2.5 million visitors to ANP annually as well as by local residents. Salt marshes are afforded legislative protection under Federal and State statutes because of their well-documented ecological importance (for example, the Natural Resources Protection Act (NRPA; Maine Legislature, undated a). The ANP Water Resources Management Plan documents the importance of maintaining the functional quality of the coastal wetlands of ANP (Kahl and others, 2000; Vaux and others, 2008).

In 2010, the U.S. Geological Survey (USGS), in cooperation with the National Park Service (NPS), began a study to map potential static landward inundation around salt marshes in ANP and its associated lands (fig. 2). The goals of the project were to map the additional salt marshes not covered by the earlier ANP vegetation survey, to map the areal extent of static landward inundation around salt marshes expected from sea-level rise (SLR) by 2100 and identify adjacent low-lying land that may provide area into which salt marshes may migrate, and to map potential artificial barriers to migration.

\section{Coastal Inundation from Sea-Level Rise and Migration of Salt Marshes}

Sea level has been rising globally for the last 20,000 years largely because of melting continental ice sheets that had accumulated during the last ice age (Poore and others, 2000). During the last 100 years, measured rates of SLR in New England ranged from 0.6 to 2.5 millimeters per year (mm/yr; Goodman and others, 2007; Kirshen and others, 2008). Historically, many New England marshes have been able to keep pace with observed rates of SLR by the accretion of sediment and organic matter (Roman and others, 1997; Goodman and others, 2007; Cahoon and others, 2009). Accretion is a complex process involving sediment supply and organic-matter accumulation. Sediment supply must be sufficient to maintain the marsh surface, and the relative importance of inorganic sediment and organic matter varies depending on local factors (Cahoon and others, 2009). Salt marshes in Maine have been found to be capable of accreting up to $4.2 \mathrm{~mm} / \mathrm{yr}$ (Goodman and others, 2007). Although maximum possible accretion rates are unknown, the rates of accretion have been found to correlate positively with tidal range (Morris, 2007). The large tidal ranges in the Gulf of 

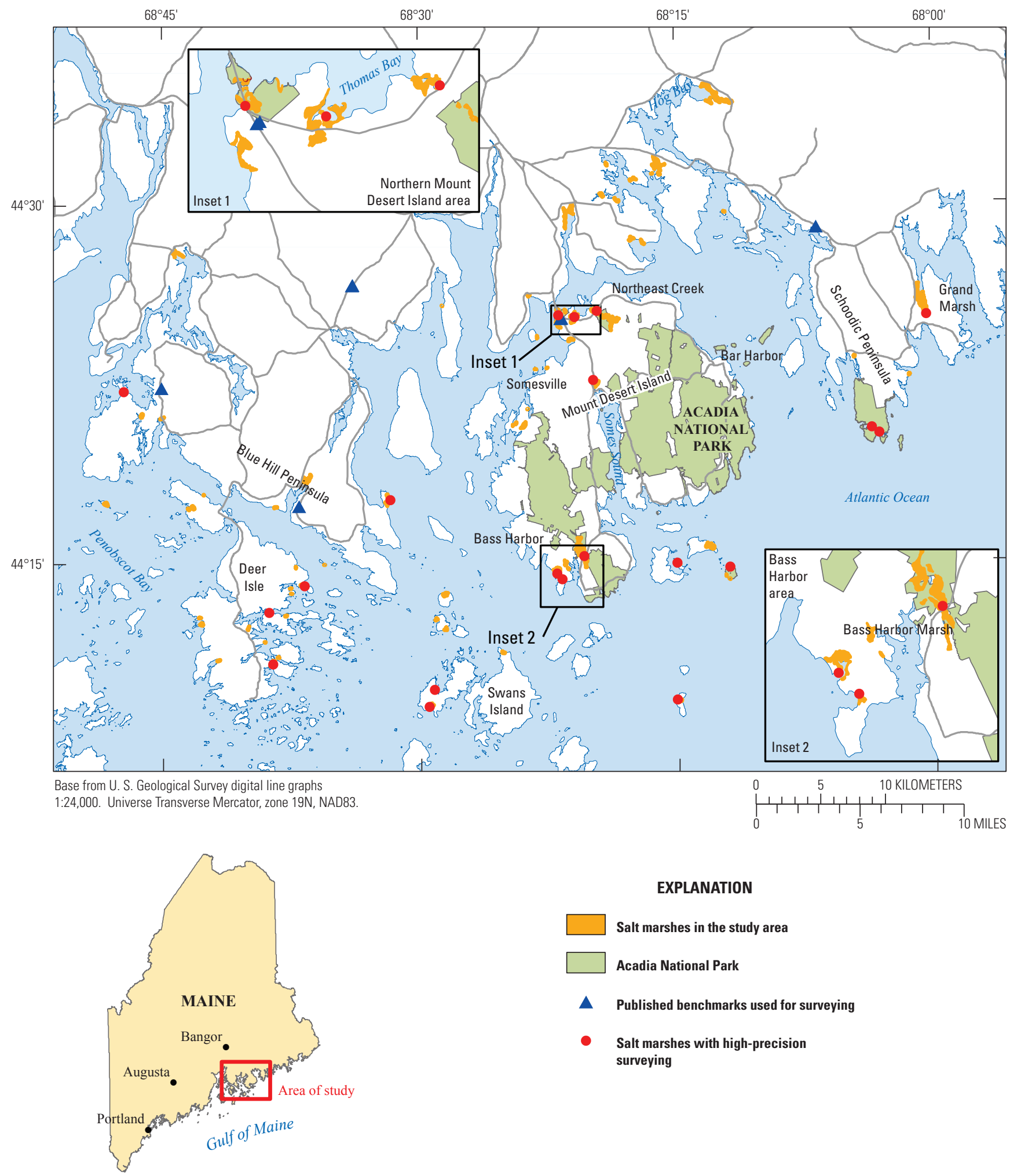

EXPLANATION

Salt marshes in the study area

Acadia National Park

A Published benchmarks used for surveying

- Salt marshes with high-precision surveying

Figure 2. Location of study area in and around Acadia National Park, Maine. 
Maine and Bay of Fundy (not shown in figures) may provide conditions favorable to faster accretion for salt marshes in Maine than for salt marshes farther south on the Atlantic coast.

One of the projected effects of climate warming is a continued rise in sea level caused by a combination of melting glaciers and polar ice and thermal expansion of the ocean (Frumhoff and others, 2007). Whereas SLR rates historically have been about 0.6 to $2.5 \mathrm{~mm} / \mathrm{yr}$, future rates may go as high as $8.4 \mathrm{~mm} / \mathrm{yr}$ (Frumhoff and others, 2007; Day and others, 2008; Kirshen and others, 2008). Although there is great uncertainty in the precise amount, a 60 -centimeter $(\mathrm{cm}$; 2 -foot) rise is cited as a 100-year planning target by the State of Maine (Maine Department of Environmental Protection, 1993). Slovinsky and Dickson (2006) used the 100 -year projected rise of $60 \mathrm{~cm}$ (2 feet) for a demonstration project mapping static inundation for an area of the Rachel Carson National Wildlife Refuge in coastal Maine.

Vertical accretion can be accompanied by horizontal transgression, or migration, of salt marshes into adjacent lowlands, provided there are no artificial barriers to prevent migration (Goodman and others, 2007; Kirwan and Murray, 2008; Cahoon and others, 2009). Artificial structures, such as roads, dikes, and seawalls, can act as barriers to salt-marsh migration in two ways: the elevated land area occupied by the structures decreases the land area available for saltmarsh formation, and barriers can act as dams and prohibit the colonization of adjacent lands by salt-marsh vegetation and restrict the vegetative transition zone at the upper marsh border (Bozek and Burdick, 2005). Some barriers may allow water passage through a culvert or bridge, but water and sediment movement may be so restricted that healthy marsh growth is not possible.

The migration of marsh surfaces onto adjacent low-lying land will be important in the overall survival of salt marshes by the year 2100, even if accretion of current (2012) marsh surfaces cannot occur fast enough to keep pace with SLR. If seaward erosion of the salt-marsh surface occurs and (or) accretion cannot keep pace with SLR, the presence of adjacent low-lying land for inland migration and the mitigation of artificial barriers to migration will be critical for maintaining salt-marsh areas (Cahoon and others, 2009). Therefore, the identification and protection of low-lying lands adjacent to existing salt marshes and the identification of migration barriers are important parts of any proactive adaptation strategy for salt-marsh persistence.

\section{Approaches and Datum Characteristics for Assessing Potential Effects of Inundation}

Several methods have been used in predicting the effect of SLR on coastal habitats, and generally can be categorized as either process-driven or static. Process-driven methods attempt to address the complex relations between SLR and natural and anthropogenic environmental drivers, accretionary processes, and geomorphic settings of salt marshes (for example, Morris, 2007; Kirwan and Murray, 2008; Craft and others, 2009). Consequently, process-driven methods are more data intensive than static inundation methods, and the need for highly intensive data collection makes process-driven methods impractical for predicting high-resolution effects at regional scales (Cahoon and others, 2009).

Static methods indicate where uplands will be submerged and where artificial structures may be threatened (for example, Slovinsky and Dickson, 2006) but do not quantify effects of erosion or accretion on coastal environments. Static methods delineate areas of inundation below a specified elevation and, therefore, rely on accurate topographic data for modeling and mapping exactly the areas that would be submerged under a given amount of SLR, absent accretion (Gesch and others, 2009). For static inundation mapping, Gesch (2009) proposes a guideline that the elevation data to be used are at least twice as accurate (as measured by the 95-percent confidence interval) as the amount of SLR being mapped. Thus, for a 60-cm SLR scenario, the topographic data used for mapping should have an accuracy of $\pm 30 \mathrm{~cm}$ or better at the 95 -percent confidence level.

The present study used a static mapping approach to evaluate the potential for inundation of salt marshes and adjacent uplands; accretion and erosion rates of marsh surfaces were not estimated. The resulting inundation delineations will help the NPS to adapt proactively to SLR by identifying, and targeting for conservation or further study, low-lying coastal wetlands that are not presently (2012) protected. In addition, the NPS will be able use the inundation delineations to propose where further study of factors affecting marsh accretion, such as sediment characteristics of salt marshes in the study area, sedimentation rates, sources of sediment transport, and hydrodynamic modeling of currents carrying sediment to and from salt marshes would be most warranted. The identification of potential migration barriers provides the means for identifying potential risks to some NPS infrastructure (such as roads or bridges) in the coastal zone, and where mitigation of those barriers may be considered.

Salt marshes exist in a narrow elevation range relative to sea level and local tides; the elevation range favorable to salt marshes can be most directly described using tidal datums. A tidal datum is a base elevation, computed on the basis of a particular phase of the tide, from which relative heights and depths are measured. Tidal datums are determined by the National Oceanic and Atmospheric Administration (NOAA) National Ocean Service's (NOS) Center for Operational Oceanographic Products and Services (CO-OPS) on the basis of a 19-year observation cycle referred to as the National Tidal Datum Epoch (NTDE). Tidal datums include, but are not limited to, mean high water (MHW), highest astronomical tide (HAT), and mean sea level (MSL). MHW is the arithmetic mean of all high water heights, HAT is the elevation of the highest predicted astronomical tide, and MSL is the arithmetic average of all hourly water height observations during a NTDE (National Oceanic and Atmospheric Administration, 2000). 
In general, high marsh vegetation, typically dominated by salt-meadow grass (Spartina patens) grows best between the local MHW and the HAT; low marsh vegetation, typically dominated by smooth cord grass (Spartina alterniflora), grows optimally between MSL and MHW (Provost, 1976; Slovinsky and Dickinson, 2006). These tidal elevation ranges in which high and low marshes are thought to grow are not defined by distinct boundaries, as the growth of high and low marsh vegetation can vary depending on local conditions such as salinity, nutrient availability, tidal range, and landscape disturbances (McKee and Patrick, 1988). The Maine Department of Environmental Protection (2012) uses the HAT to locate the upland edge of coastal wetlands for regulatory purposes (http://www.maine.gov/dep/land/slz/predictions.pdf, accessed July 11, 2012), under the NRPA and the Mandatory Shoreland Zoning Act (Maine Legislature, undated b). For this study, high and low marshes were considered together during the mapping of areas considered to be salt marsh and a different method was used to define the upland edge of the salt marshes.

As tidal datums vary from location to location because of differing hydrographic characteristics, in the interest of transferability of results it is most useful to present the data in terms of global datums that do not depend on mean sea level (a tidal datum). In this study area, the tidal datum of local mean sea level is 5 to $10 \mathrm{~cm}$ lower than $0 \mathrm{~m}$ North American Vertical Datum of 1988 (NAVD88; according to local conversions done using the VDatum datum converter (National Oceanic and Atmospheric Administration, 2012c)). Therefore, all elevations for this study were computed relative to the global NAVD 88, and horizontal coordinates were located relative to North American Datum of 1983 (NAD 83) (Continuously Operating Reference Stations (CORS) 96, Epoch 2002).

\section{Purpose and Scope}

This report describes the mapping of contour lines adjacent to salt marshes that show areas that would be inundated in a SLR scenario of $60 \mathrm{~cm}$ (2 feet) in and around ANP and includes the identification of potential barriers to future salt-marsh migration. The report includes descriptions of the data and methodology used to conduct the mapping and to conduct an independent evaluation of the elevationdata accuracy and the derivation of 95-percent confidence intervals for the inundation contours. The inundation contours indicate which lowlands adjacent to existing salt marshes may provide potential areas for migration of salt-marsh habitat. The mapped inundation contours are accompanied by 95 -percent confidence interval contours determined on the basis of an independent accuracy assessment of the saltmarsh-specific topographic data used for mapping. This report presents example maps showing the inundation contours and the 95-percent confidence interval contours around those contours. A geodatabase accompanying this report presents all the inundation contours produced by this study, along with the surveying data and locations of all the salt marshes used in the study. The geodatabase is a data management framework used to store and easily access geospatial data for a variety of applications.

\section{Land-Surface Elevation Data}

The elevation range that defines the physical bounds of marsh ecology is relatively small; it is, therefore, important to use accurate regional land-surface elevation data (topographic data) to delineate the extant marsh boundaries and adjacent regions estimated to be inundated by SLR (Gesch, 2009). This study made use of topographic data collected by use of a remote sensing technique generally referred to as "light detection and ranging" (LiDAR). Airborne laser surveying (ALS) is a type of LiDAR data collection done from an aircraft. ALS serves as a rapid and relatively accurate method for collecting topographic data over large areas (Brock and Sallenger, 2001). LiDAR data routinely achieve vertical accuracy on the order of a 15-cm RMSE, have been successfully used in flood modeling applications, and are well suited for mapping inundation of low-relief areas, such as coastal wetlands (Gesch, 2009; Gesch and others, 2009).

LiDAR topographic data were collected in October 2010 by Photo Science, Inc. for the Atlantic shoreline from Long Island, New York, to the border of Canada and Maine using ALS methods. Photo Science, Inc. derived digital elevation models (DEMs) from the LiDAR data with a 2-meter (m) horizontal resolution. The DEMs were used in this study to help map present marsh boundaries, estimate SLR inundation boundaries, and define artificial structures that may present barriers to the migration of salt marshes.

\section{Land Surveying}

USGS staff established land-surveyed control points in the ANP study area as part of an independent evaluation of the accuracy of the LiDAR data specific to salt-marsh land-cover types. Five control points were surveyed at each of 20 selected marshes across the study area (fig. 2) for a total of 100 points. The marshes used in the USGS control-point land surveys were chosen to represent the size range and geographic distribution of all marshes in the study area.

An elevation reference mark (ERM) was established in the vicinity of each of the 20 salt marshes to maintain vertical control near the marshes (fig. 3A). The ERMs also will serve as stable datum points to support future salt-marsh research. ERMs established for this study were documented with latitude and longitude coordinates, location descriptions, and photographs. These data were uploaded to the NPS Denver Service Center (DSC) survey monuments database (Benjamin Zank, National Park Service Denver Service Center, written commun., July 14, 2011). The NPS DSC survey monuments 
database stores these spatial data for all National parks and enables convenient access by ArcGIS clients.

The elevations of the ERMs were determined using Leica high-precision (millimeter accuracy) dual-frequency global-positioning system (GPS) receivers (fig. 3B). This technique (referred to as "high-precision surveying") uses a GPS receiver (base) set on (occupying) a survey monument or published benchmark (fig. 2) that has a known elevation; base-unit occupy times ranged from 5 hours (hr) to $10 \mathrm{hr} 53$ minutes (min); the average occupy time was $7 \mathrm{hr} 33 \mathrm{~min}$. The base units received GPS signals from United States GPS satellites, computed a positional error, and broadcast the error to a second GPS receiver (rover) that occupied an ERM. Rover-unit-occupy times ranged from 15 to $48 \mathrm{~min}$ with an average occupy time of $30 \mathrm{~min}$.

Base-receiver data were submitted to the National Geodetic Survey (NGS; National Oceanic and Atmospheric Administration, 2012c) using the Online Positioning User Service (OPUS) precise processing service (http://www.ngs. noaa.gov/OPUS/about.jsp, accessed June 25, 2012). Basepoint elevations were solved by OPUS using the network of Continuously Operating Reference Stations (CORS; National Oceanic and Atmospheric Administration, 2012a).
Root mean square errors (RMSE) for OPUS base-point elevation solutions ranged from 1.5 to $1.8 \mathrm{~cm}$, with a mean of $1.6 \mathrm{~cm}$. Rover receiver data were used in conjunction with base-point elevation solutions to compute ERM elevations. ERM elevations were solved using Leica GeoOffice (LGO) 2.0 software. GEOID09 is the geoid model used to convert ellipsoid heights to orthometric heights above NAVD 88. Elevation solutions between base points and ERMs had standard deviations that ranged from 0.05 to $0.51 \mathrm{~cm}$ (average $0.14 \mathrm{~cm}$ ).

Five control points were established on each marsh using wooden stakes that were set flush with the bare ground level (fig. 3C). The marsh control points were located on flat terrain within each marsh with a minimum spacing of $10 \mathrm{~m}$ between points. Control-point elevations were then surveyed relative to nearby ERMs using a Sokkia Set 4B Total Station (TS) infrared laser transit and survey rods with retro-reflectors (prisms). The Sokkia TS provided 5-second angular precision and millimeter-scale precision in both distance and elevation with shots up to 1 kilometer $(\mathrm{km})$ distant, depending on atmospheric conditions. Potential errors were controlled by resurveying if survey loops did not close to less than $2.0 \mathrm{~cm}$.

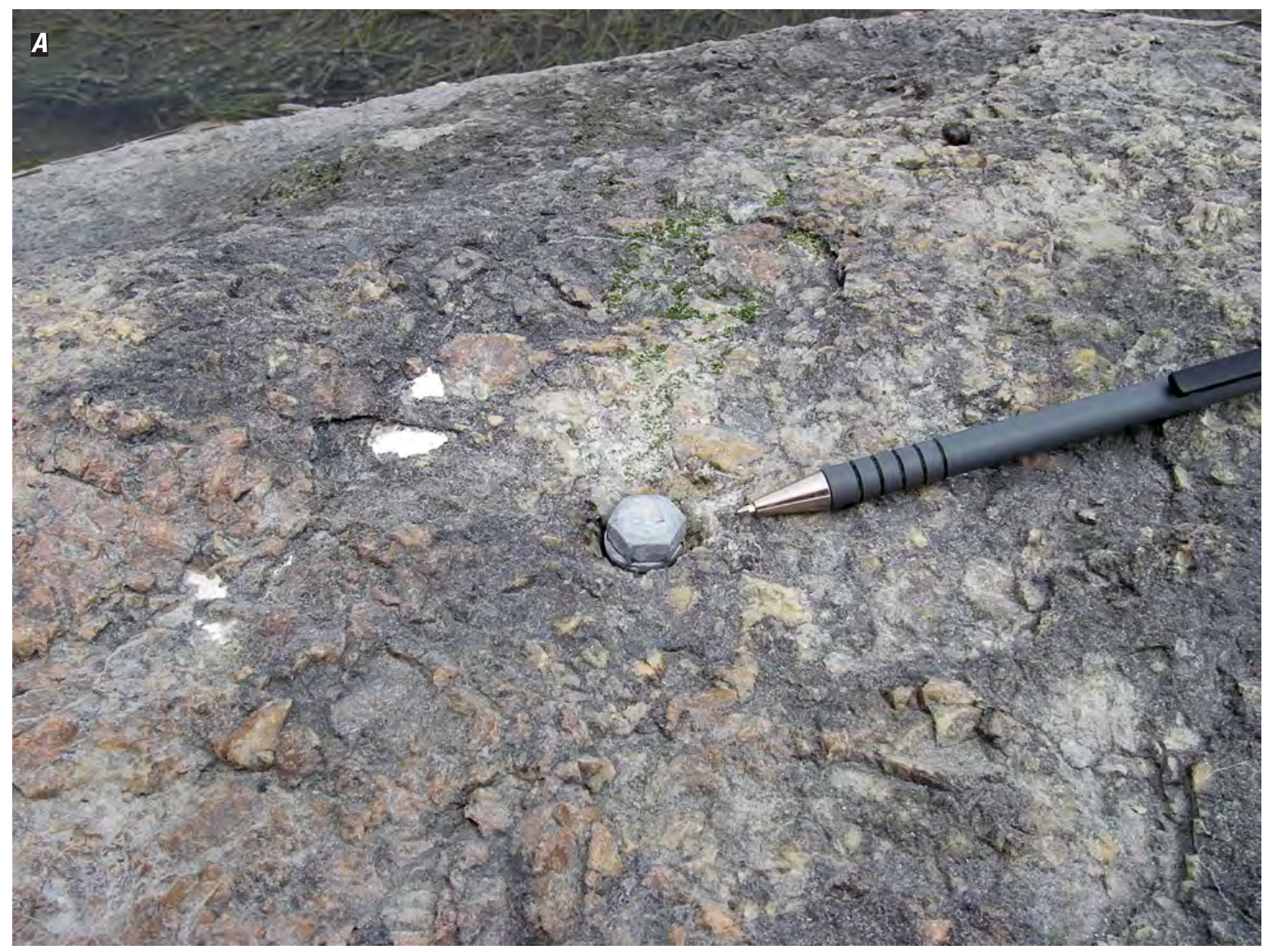

Figure 3. A, a lag bolt anchored in bedrock that serves as an elevation reference mark, $B$, a global-positioning system (GPS) receiver placed on an elevation reference mark, and $C$, a wooden stake flush with the marsh surface that serves as a control point. 

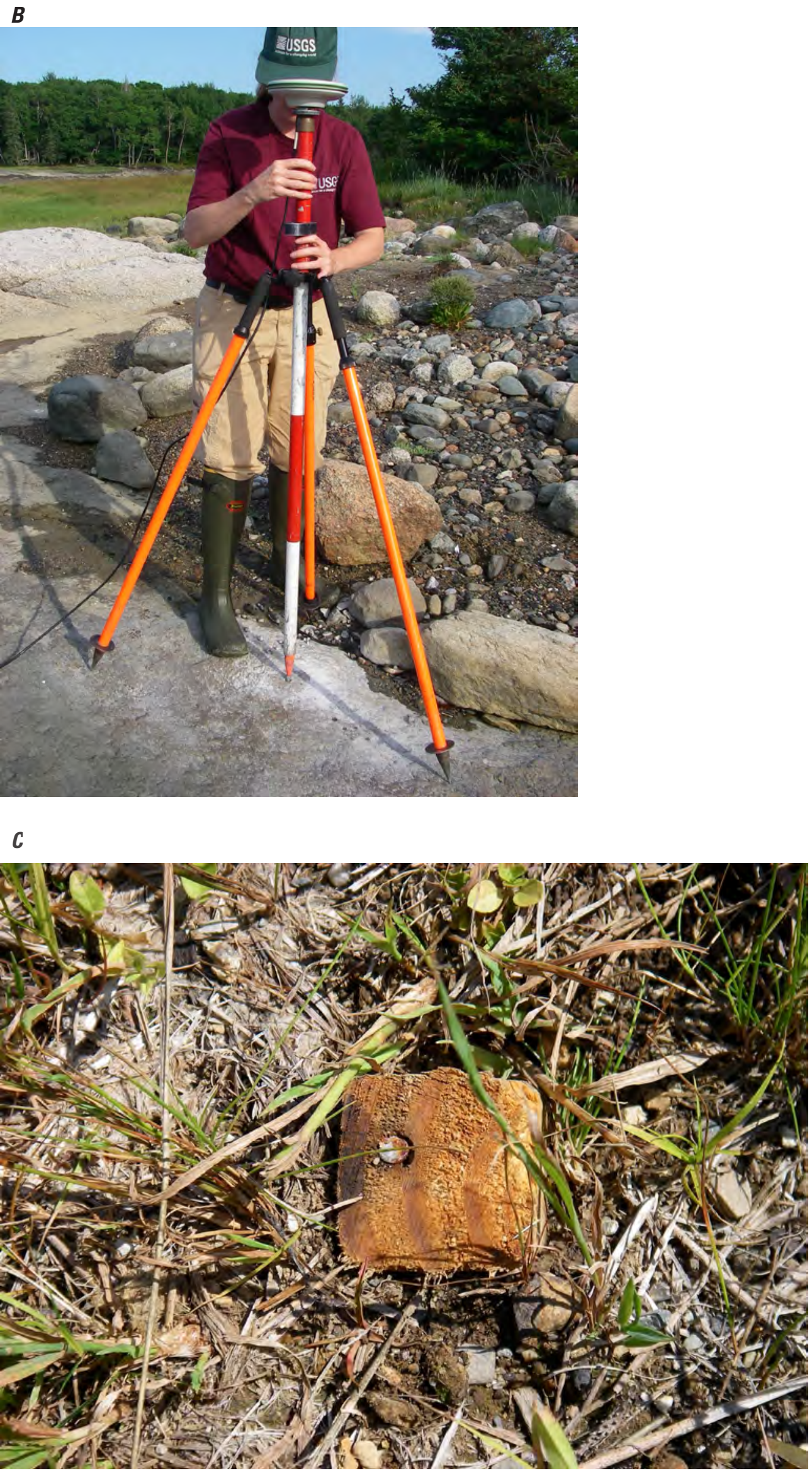

Figure 3. $A$, a lag bolt anchored in bedrock that serves as an elevation reference mark, $B$, a globalpositioning system (GPS) receiver placed on an elevation reference mark, and C, a wooden stake flush with the marsh surface that serves as a control point.-Continued 


\section{Vertical Accuracy Assessment for Land-Surface Elevation Data}

Photo Science, Inc. contracted land surveyors James W. Sewall Company (Co.) to locate control points throughout coastal Maine on relatively flat terrain that generally consisted of grass, gravel, or bare earth for evaluating the accuracy of the collected LiDAR data. The reported overall accuracy the LiDAR data was assessed using 44 control points subsampled from control points established by James W. Sewall Co. and the USGS. Vertical errors between LiDAR data and the 44 control points ranged from -24.2 to $18.7 \mathrm{~cm}$, with a mean of $-2.8 \mathrm{~cm}$ and RMSE of $11.3 \mathrm{~cm}$. A RMSE of no greater than $9.25 \mathrm{~cm}$ is equivalent to the accuracy required for 1-foot contour-interval mapping, and an RMSE of no greater than $18.5 \mathrm{~cm}$ is equivalent to the accuracy required for 2-foot contour-interval mapping (National Digital Elevation Program, 2004).

The independent accuracy assessment of LiDAR topographic data in comparison to land-surveyed control points was conducted by the USGS in selected salt marshes in the study area quantify the uncertainty of inundation contours for a $60-\mathrm{cm}$ projected SLR. This accuracy assessment was done using LP360, a plug-in for ArcGIS. Because of limitations on LiDAR data availability during this study, only 57 of the 100 USGS-surveyed control points were used for the independent accuracy assessment. Vertical errors between LiDAR data and 57 USGS land-surveyed control points at salt-marsh surfaces ranged from -20.2 to $41.8 \mathrm{~cm}$, with a mean of $5.9 \mathrm{~cm}$ and RMSE of $13.3 \mathrm{~cm}$. A small observed positive bias $(+5.9 \mathrm{~cm})$ was not unexpected because the presence of dense marsh grass overlying the ground likely prevented penetration of many LiDAR signals to the marsh surface.

The RMSE of the LiDAR data were used to calculate the 95-percent confidence interval of the elevation data. The 95th percentile method may be used regardless of whether the errors follow a normal distribution or qualify as outliers (National Digital Elevation Program, 2004). From the 57 marsh-surface control points used, the LiDAR data had a 95 -percent confidence interval of $\pm 26.0 \mathrm{~cm}$, which falls within the accuracy threshold of $\pm 30 \mathrm{~cm}$ recommended by Gesch (2009) for modeling static inundation of a 60-cm SLR.

\section{Salt-Marsh Inventory}

Digital color aerial photography was used to verify and update boundaries identified in the 1997 vegetation survey produced for the Acadia National Park Vegetation Mapping Project, USGS-NPS Vegetation Mapping Program for Mount Desert Island (MDI), Schoodic Peninsula, and ANP holdings and easements on outlying islands (fig. 2; Lubinski and others, 2003) and to identify additional significant (larger than $1 \mathrm{ha}$ ) salt marshes in all the coastal areas from eastern Penobscot Bay to Grand Marsh. Conservation partners, especially the Maine Coast Heritage Trust, were consulted to help identify additional salt marshes for inclusion in the study. Salt marshes were located and verified with the aid of various sets of high-resolution aerial photos, taken at different seasons and in different years, provided by several online mapping services (Google Maps ${ }^{\mathrm{TM}}$, Bing! ${ }^{\mathrm{TM}}$ ) and digital color aerial photography from eastern Penobscot Bay to Schoodic Point, consisting of high-resolution 24-bit color orthorectified digital images (ODIs) with a pixel resolution of 0.5 meters, which was used as the primary source. The photographs were taken by J.W. Sewall Co. during August 2008 at and near low-tide conditions. These digital 2008 low-tide photos are geo-referenced and suitable for applications requiring a 1:2400 National Map Accuracy Standard (NMAS). The aerial photography was accessed using the Maine Geolibrary (2011) Web mapping services application, which serves the photography as a seamless mosaic.

The 1997 ANP vegetation survey identified 47 salt marshes in and near the park. This survey verified those salt marshes and identified an additional 67 salt marshes within the study area. A total of 114 salt-marsh areas were identified. Large salt-marsh complexes were split into several marshes on the basis of physical proximity and congruity, and the locations of major water bodies separating different parts of the marsh complexes. Very small fringing salt marshes ( $<0.2$ ha, or having widths of $3 \mathrm{~m}$ or less) are not well represented in the survey, particularly outside the ANP boundary. They are difficult to distinguish even on goodquality aerial photos, and there were no existing maps of their locations outside the earlier ANP vegetation study.

The marshes in the study area encompass a total area of 340 ha and range in size from 0.11 ha to 52 ha (Grand Marsh, which is located northeast of the Schoodic Peninsula; fig 2). The median salt marsh size was 1.0 ha (fig. 4). Only a very few marshes are larger than 10 ha-the marshes associated with the Northeast Creek estuary and Bass Harbor Marsh, both of which are represented by several different marshes in the database, and large series of marshes at the end of Hog Bay, north of Mount Desert Island. Most of the marshes in the database are fairly small, isolated marshes. Marshes within ANP boundaries and easements held by ANP accounted for 26 of the marshes (23 percent), and the State of Maine accounted for 1 of the 114 marshes.

The towns of Gouldsboro, Bar Harbor, Franklin, and Tremont had the greatest area of salt marshes in the study area (table 1, fig.5), many of which were in large salt marshes and salt marsh complexes. Deer Isle and Trenton each have a relatively large number of small salt marshes. Ten of the 22 towns in the study area are host to salt marshes on ANP lands; Bar Harbor, Frenchboro, Tremont, Trenton, and Southwest Harbor all have more than 5 ha in salt marsh habitat within the ANP landholdings (table 1). 


\section{Estimated Future Inundation Resulting from Sea-Level Rise at Salt Marshes}

The delineation of inundation contours from any given amount of SLR assumes a common datum for all the salt marshes involved in the study. Because of the ecological niche occupied by salt marshes, the HAT could be used as a common datum. However, there is no available spatial dataset representing HAT in the study area and the numerous islands and tidal restrictions in many bays and estuaries create great spatial variability in the HAT datum. This study, therefore, used the highest marsh elevation (HME) at each salt marsh as a proxy for the local HAT. The inundation mapping was done relative to the highest elevation of each marsh surface, derived from the LiDAR data. The HME was determined in an iterative fashion. After the marsh extent was mapped using the high-resolution aerial photos available for the marsh, as described above, the LiDAR DEM data were used to find the highest elevation of the marsh at the upland edge, where the marsh transitioned into other ecosystems (in many locations this was a very abrupt transition, whereas in others the transition was more gradual). Next, a contour was drawn at that elevation and compared to the marsh upland boundary as mapped using the aerial photos. The process was repeated until a contour elevation was found that best delineated the marsh-upland boundary, and that elevation was defined as the HME (fig. 6).

Inundation contours were delineated at each salt marsh using an elevation of the $\mathrm{HME}+60 \mathrm{~cm}$ to indicate adjacent lowlands that are expected to be inundated from $60 \mathrm{~cm}$ of SLR and would be available for the potential migration of the marsh. The 95-percent confidence interval on the LiDAR elevation data $( \pm 26.0 \mathrm{~cm})$ was mapped relative to the estimated HME $+60-\mathrm{cm}$ SLR elevation line by defining an upper and lower 95-percent confidence interval contour on either side of the 60-cm inundation contour (fig. 6). The differences in inundated areas between the upper and lower 95-percent confidence interval contours are the spatial
Table 1. Inventory of salt marshes in towns within the study area, including number of marshes and total marsh areas for areas with Acadia National Park.

[ha, hectares; ANP, Acadia National Park; --, none; Note: some of the salt marshes are located on the border between towns and appear more than once on the list]

\begin{tabular}{|c|c|c|c|c|}
\hline Town & $\begin{array}{c}\text { Total } \\
\text { salt marsh } \\
\text { area, } \\
\text { in ha }\end{array}$ & $\begin{array}{c}\text { Number } \\
\text { of } \\
\text { salt } \\
\text { marshes }\end{array}$ & $\begin{array}{c}\text { Total } \\
\text { salt marsh } \\
\text { area } \\
\text { in ANP }\end{array}$ & $\begin{array}{c}\text { Number } \\
\text { of salt } \\
\text { marshes } \\
\text { in ANP }\end{array}$ \\
\hline Bar Harbor & 46.8 & 14 & 18.2 & 7 \\
\hline Brooklin & 8.8 & 5 & 0.3 & 1 \\
\hline Brooksville & 11.1 & 5 & -- & -- \\
\hline Cranberry Isles & 15.7 & 4 & 0.8 & 2 \\
\hline Deer Isle & 11.1 & 17 & 3.6 & 1 \\
\hline Franklin & 37.1 & 4 & -- & -- \\
\hline Frenchboro & 10.5 & 2 & 6.5 & 1 \\
\hline Gouldsboro & 52.8 & 2 & -- & -- \\
\hline Hancock & 20.5 & 8 & -- & -- \\
\hline Lamoine & 18.0 & 6 & -- & -- \\
\hline Mount Desert & 13.4 & 6 & -- & -- \\
\hline North Haven & 0.1 & 1 & -- & -- \\
\hline Penobscot & 4.1 & 2 & -- & -- \\
\hline Sedgwick & 6.0 & 3 & -- & -- \\
\hline Sorrento & 0.3 & 1 & -- & -- \\
\hline Southwest Harbor & 14.9 & 6 & 14.9 & 6 \\
\hline Stonington & 5.1 & 4 & -- & -- \\
\hline Surry & 0.2 & 1 & -- & -- \\
\hline Swans Island & 10.4 & 5 & 5.4 & 4 \\
\hline Tremont & 33.1 & 8 & 18.1 & 5 \\
\hline Trenton & 11.9 & 10 & 5.8 & 7 \\
\hline Winter Harbor & 2.6 & 4 & 1.6 & 3 \\
\hline
\end{tabular}

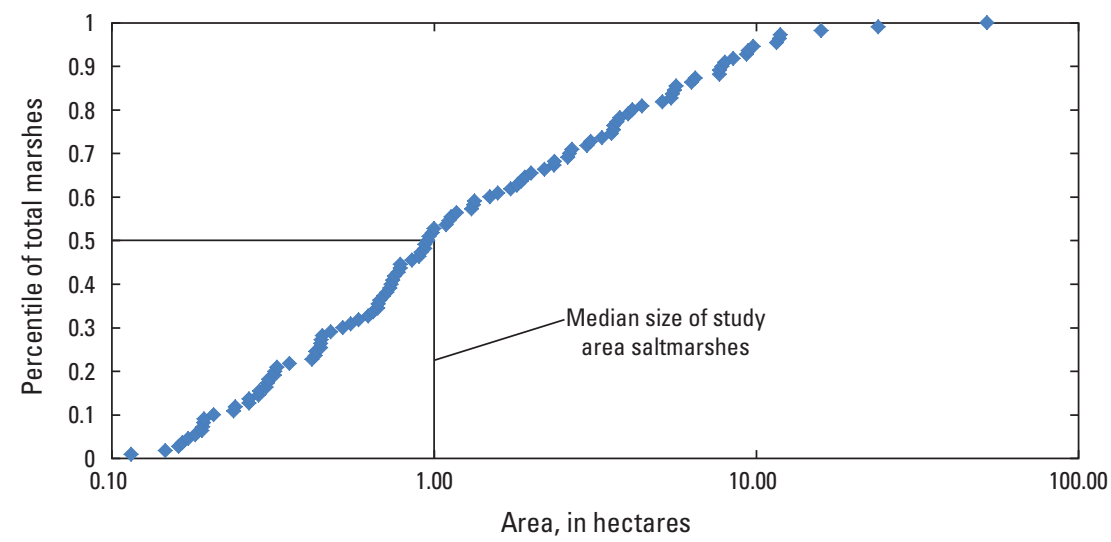

Figure 4. Cumulative distribution of salt marsh areas, in hectares. 


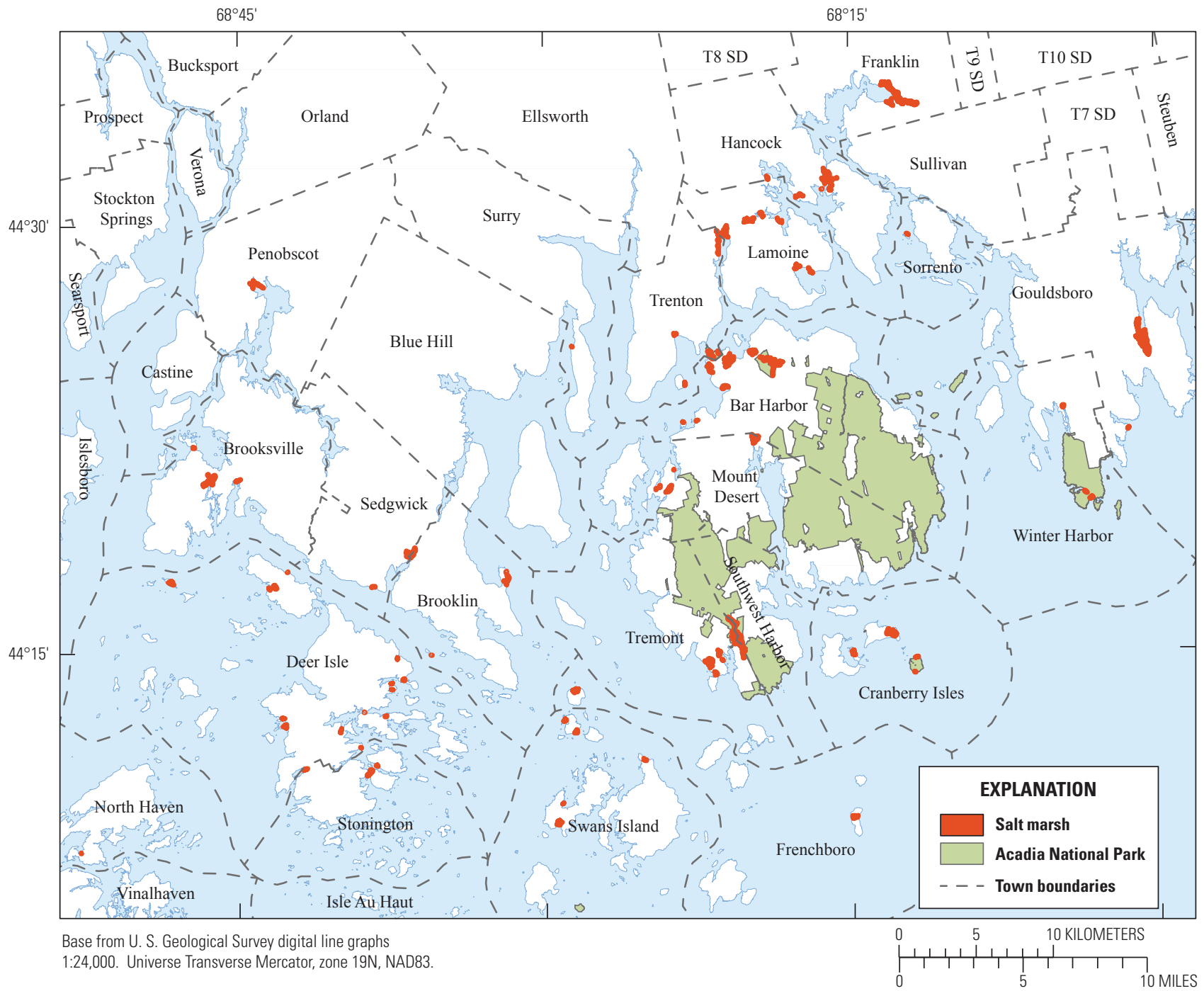

Figure 5. Distribution of salt marshes within the coastal towns in the study area.

representations of uncertainty associated with the topographic data used to produce the inundation maps and can be thought of as an uncertainty zone (fig. 6). For marshes in a low-relief setting, such as in Northeast Creek or Bass Harbor Marsh, the uncertainty zone can cover 100 to $300 \mathrm{~m}$ of distance on the ground. In areas where relief is higher, such as in Somesville at the head of Somes Sound, the uncertainty zone covers a distance of only $10 \mathrm{~m}$ or less.

Artificial structures, such as roads or bridge abutments, that could act as potential barriers to salt-marsh migration were identified and mapped. The geodatabase identifies which of the potential barriers are associated with one of the 26 salt-marsh areas of ANP and its conservation partners. These potential barriers represent ANP infrastructure that could be affected by SLR in the future, some of which could be mitigated to improve the availability of uplands for marsh migration.

\section{Inundation Potential and Barriers to Migration}

A set of four contour lines were delineated for each salt marsh in the study area (fig. 6):

- a contour line representing the HME

- the inundation contour line for $60 \mathrm{~cm}$ of SLR

- the contour line of the upper 95-percent confidence interval above the $60-\mathrm{cm}$ SLR line (SLR $+26 \mathrm{~cm})$

- the contour line of the lower 95-percent confidence interval below the $60-\mathrm{cm}$ SLR line (SLR-26 cm) 


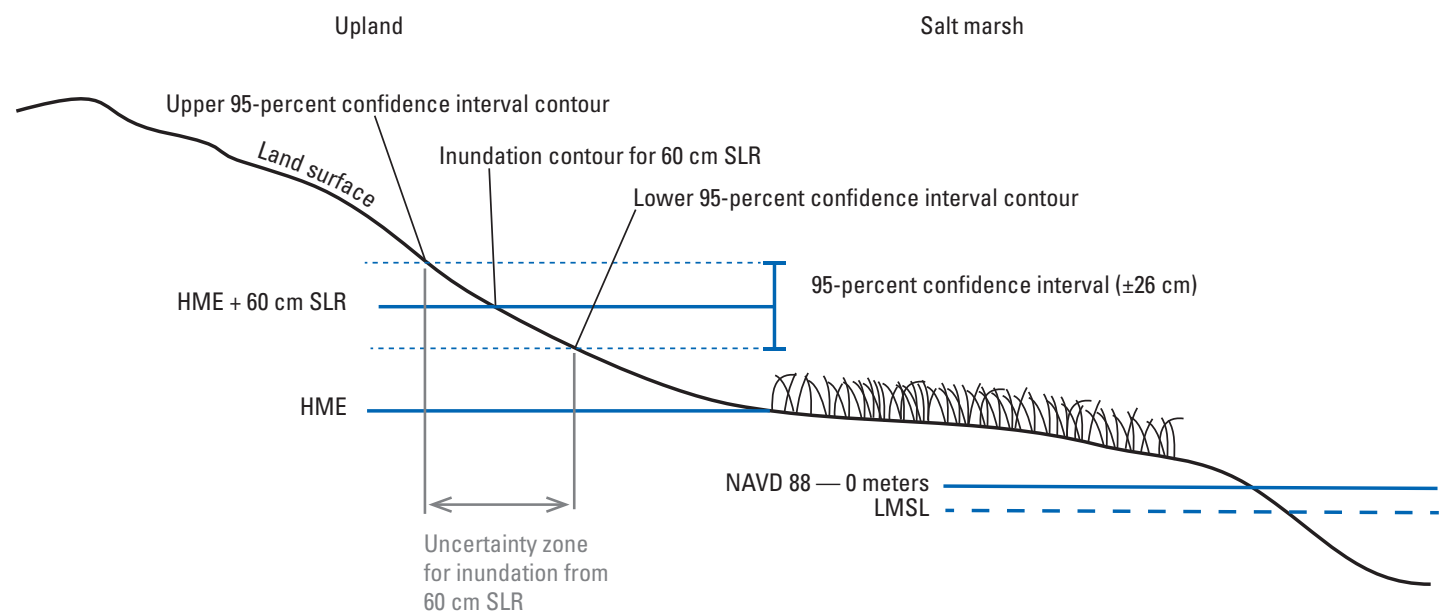

DRAWING NOT TO SCALE

Figure 6. Relation of local elevation datum to the inundation contours, 95-percent confidence interval contours, and the inundation uncertainty zone for salt marshes in the study area. cm, centimeter; HME, high marsh elevation; LMSL, local meal sea level; NAVD 88, North American Vertical Datum of 1988; SLR, sea-level rise

These delineations were stored as a polyline data layer in the geospatial data accompanying this report (appendix 1). The geospatial data are described in appendix 1 and are available for download at http://pubs.usgs.gov/sir/2012/5290/.

Inundation contours at 110 marshes were mapped during this study. Inundation contours were not mapped for the 4 marshes smaller than 0.2 ha on private property. The contour lines are truncated along the shoreline at the edge of the salt-marsh areas. The inundation contours are not meant as a forecast of areas into which salt marshes will migrate. Rather, they provide a basis for planning management decisions and a basis for further study of factors such as sediment supply and current accretion rates for determining site-specific potential for migration.

Although this study does not attempt to predict whether any of the salt marshes in the study area will be able to keep up with sea-level rise, it may be useful to understand how those salt marshes are situated in the topographic landscape. Some of the marshes are constrained within fairly steep topographic boundaries and have little room to expand or migrate, while others are located in broad lowland areas; many others are somewhere in between these two extremes. Two measures of this "room to expand" were evaluated for the population of salt marshes in the study area - an estimate of the area that would be inundated adjacent to each salt marsh, in comparison to the original marsh area, and the average distance inland that the inundation contour lies from the marsh edge. Because the mapping of the SLR lines did not create polygons, a visual estimate of the inundated area was generated for every marsh in the study. The visual estimates were calibrated based on polygons were created for a few of the largest marshes (including the Northeast Creek and Bass Harbor marsh areas).

In total, the amount of land adjacent to the study marshes that will be inundated with $60 \mathrm{~cm}$ of SLR is estimated to be approximately 350 ha, which is about the same amount of area that the salt marshes now occupy (340 ha). But this total inundation area is not evenly distributed across the study area. Upland areas expected to be inundated near 19 of the salt marshes are much smaller than the areas occupied by those marshes ( 25 percent of the size (in 2010) or smaller; fig. 7). Only a few of the marshes have relatively large areas for possible migration (more than 200 percent of their size in 2010). While salt marshes in ANP account for just 23 percent of all the marshes in the study, two large areas within ANP (Northeast Creek and Bass Harbor Marsh) account for 170 ha (50 percent) of the total amount expected to be inundated. Similarly, the average distance inland from the current marsh edge to the inundation contour in 83 of the 110 salt marshes (75 percent) is only 20 meters or less (fig. 8). There are only 7 marshes that have an average of over 75 meters of inland expansion area directly adjacent to their perimeter. Fringing marshes in general have very little room for migration or expansion in their adjacent upland areas.

Two examples of marshes with very different landscape positions are shown in figures 9 and 10. The marsh in Somesville at the head of Somes Sound (fig. 9) has an upland area inside the $60-\mathrm{cm}$ inundation contour that is less than 25 percent of the current (2012) marsh area and has little room for expansion or migration. In contrast, the amount of area expected to be inundated in the Northeast Creek area (fig. 10) is more than 600 percent larger than the current (2012) area of the marsh (Bass Harbor Marsh has a similarly large area of 


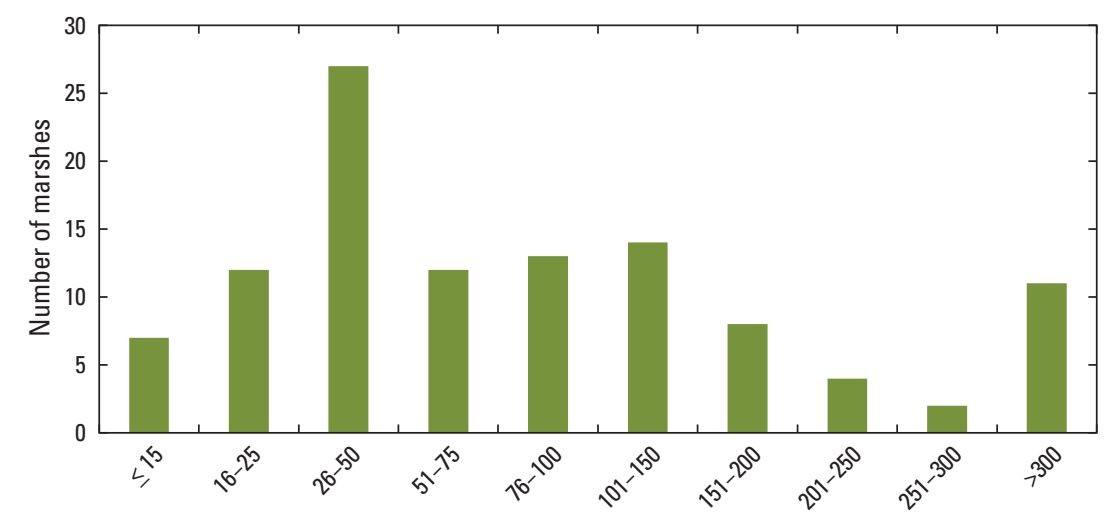

Area of upland inundated, as a percentage of marsh area

Figure 7. Histogram showing the estimated area of upland adjacent to salt marshes that will be inundated with 60 centimeters of sea-level rise, shown as a percentage of adjacent salt marsh area. $<$, greater than; $\leq$, less than or equal to.

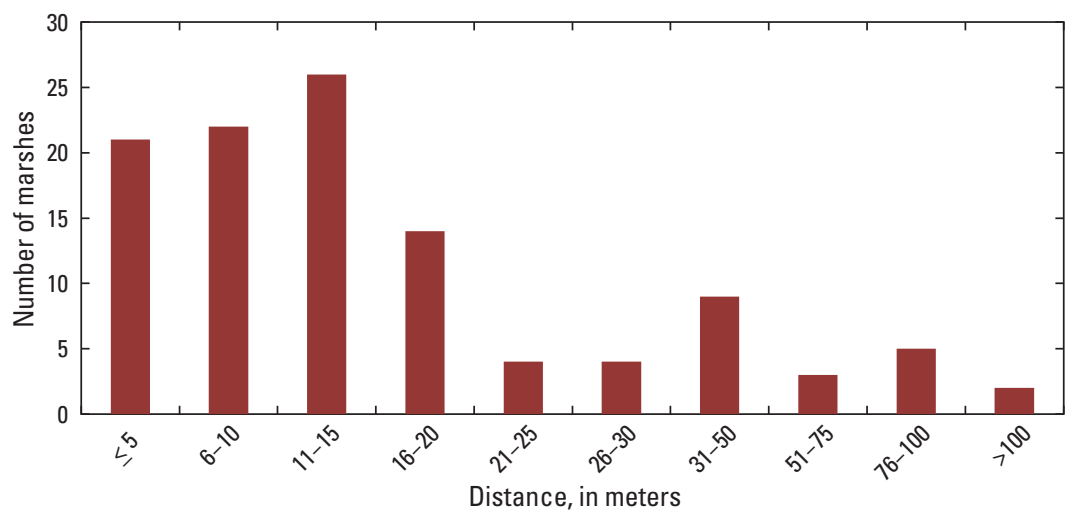

Figure 8. Histogram showing the average distance of the 60-centimeter inundation contours inland from salt marsh edges. $<$, greater than; $\leq$, less than or equal to. 


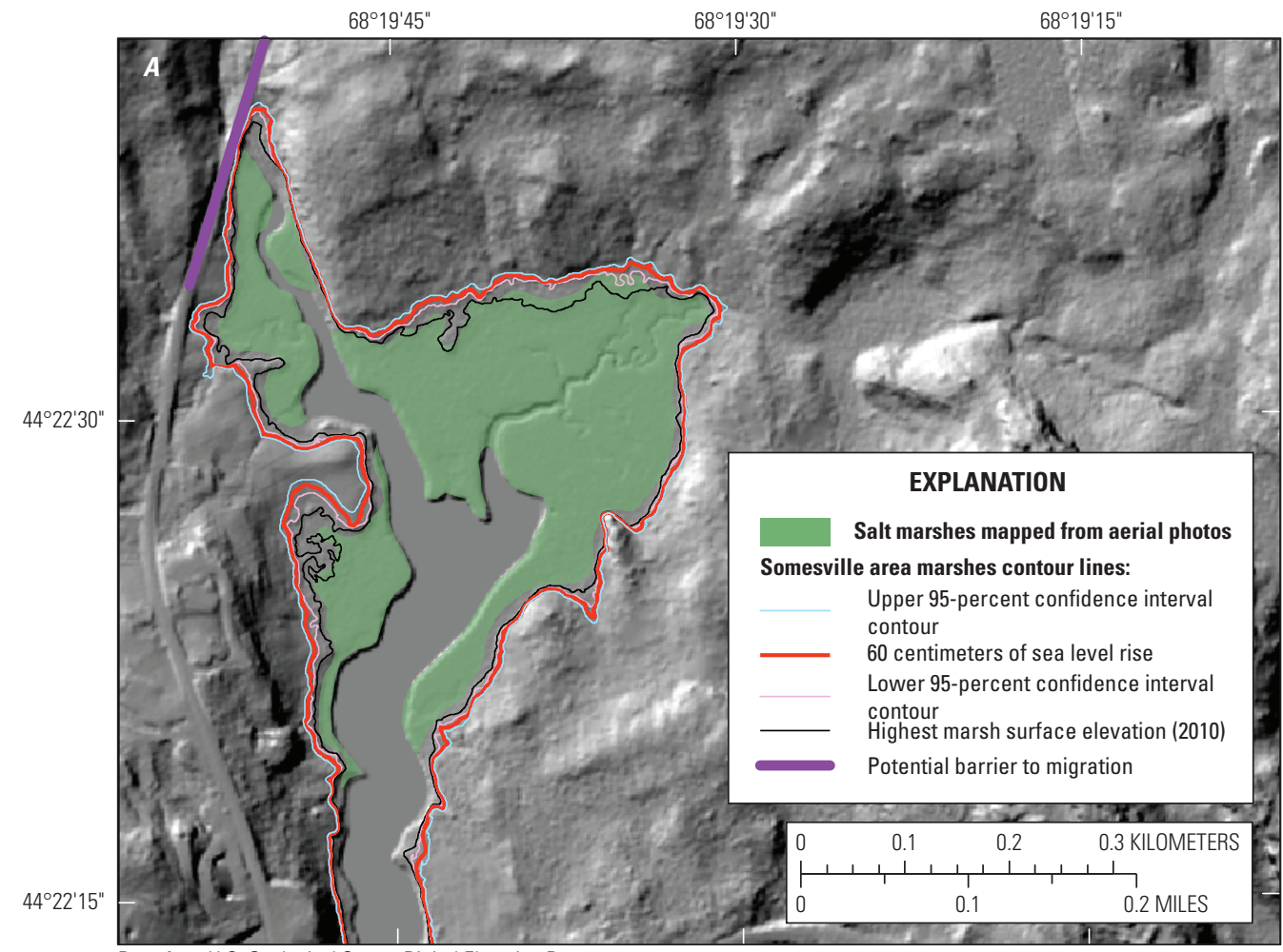

Base from U.S. Geological Survey Digital Elevation Data:

LiDAR for the Northeast, USGS Contract G10PC00026.

Photo Science, Inc., 2011

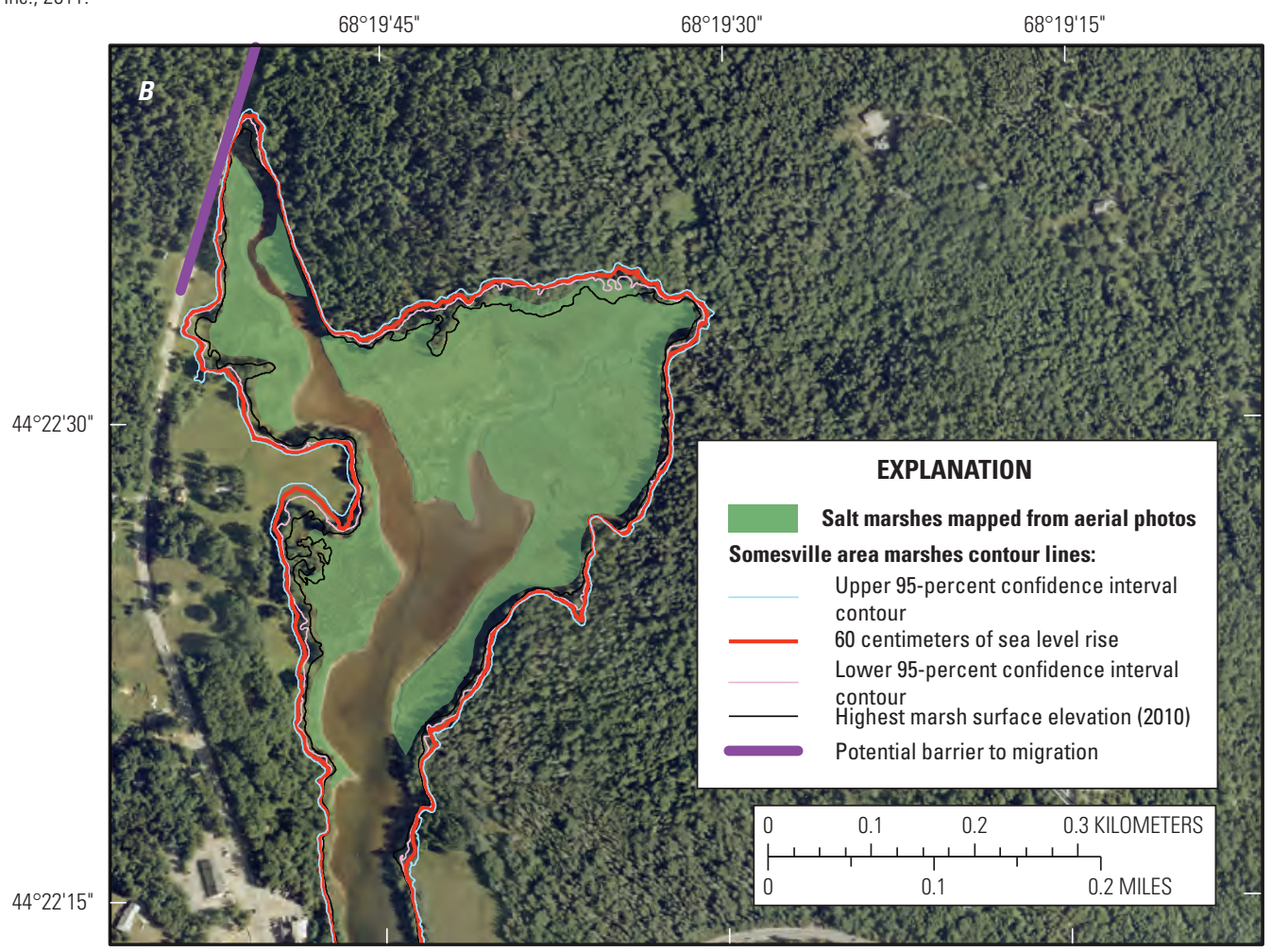

Base image credit: Maine Coastal Low Tide Ortho-rectified Digital Images, 2008 Maine Office fo Geographic Information Systems (MEGIS).

Figure 9. Static inundation map for 60 centimeters $(\mathrm{cm})$ of sea-level rise and upper and lower 95-percent confidence interval contours for the Somesville area, Mount Desert, Maine, using $A$, shaded relief image of light detection and ranging (LiDAR) data and $B$, orthophoto base. The average distance of the $60-\mathrm{cm}$ inundation contour to the current marsh edge is about 15 meters. The area between the 2010 high marsh elevation and the $60-\mathrm{cm}$ inundation contour is less than 25 percent of the marsh area in 2010. 

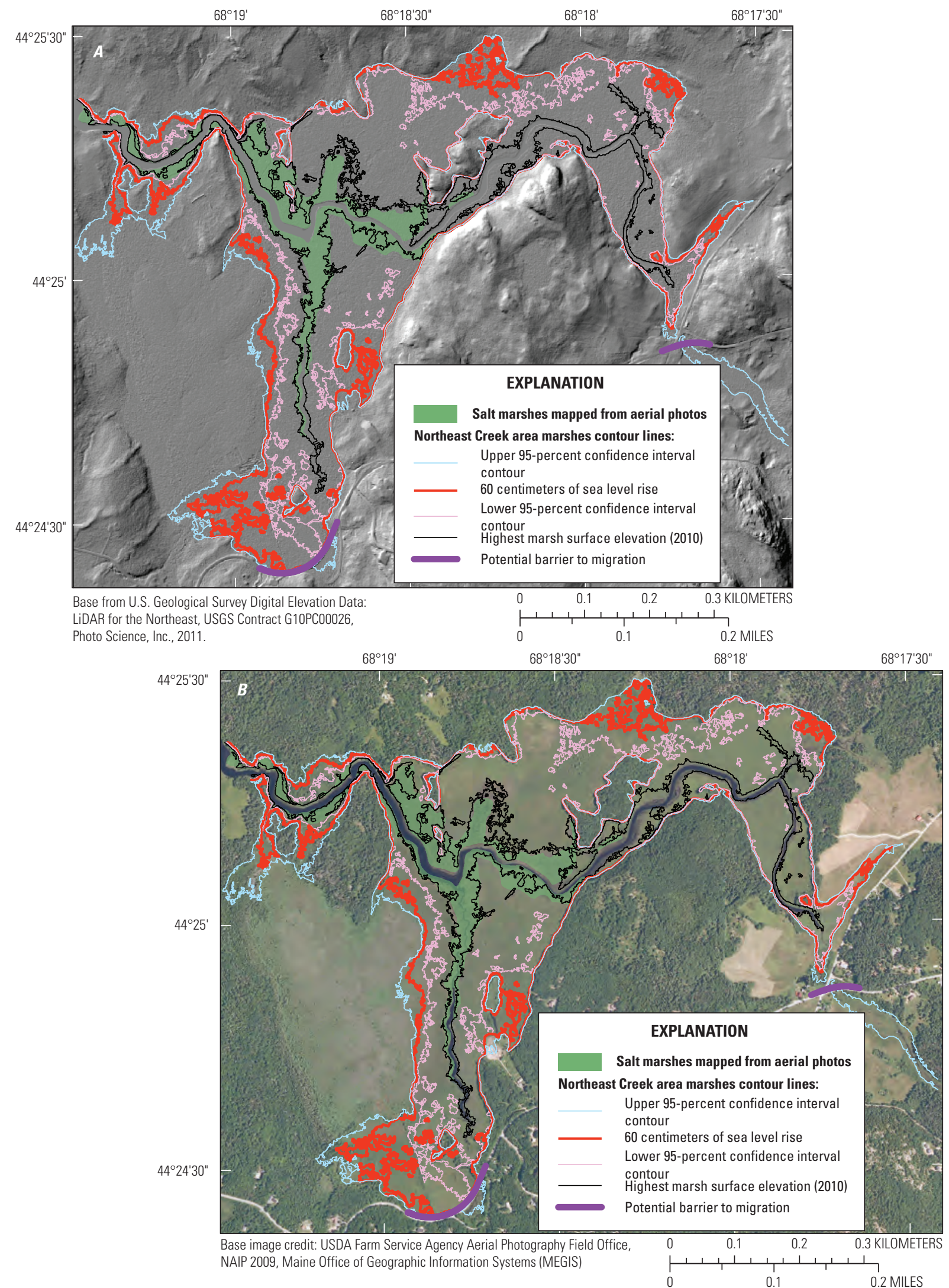

Figure 10. Static inundation map for 60 centimeters $(\mathrm{cm})$ of sea-level rise and upper and lower 95-percent confidence interval contours for the Northeast Creek area, Bar Harbor, Maine, using $A$, shaded relief image of light detection and ranging (LiDAR) data and $B$, orthophoto base. The area between the 2010 high marsh elevation and the 60 -centimeter inundation contour is more than six times the size of the marsh in 2010. 
low-relief upland that would be inundated). In both cases, the areas expected to be inundated are largely freshwater wetlands at present.

After the extent of the inundation contours were determined, the landscape around the salt marshes and inundated areas were surveyed for artificial structures that either currently impede water movement or would at a higher sea level. A total of 41 potential barriers to marsh migration were identified in and around the 110 salt marshes analyzed in the study area; examples are shown in figure 11. All but two of the potential barriers were roadways. The other two potential barriers are part of an old railroad grade. While many of the potential barriers identified do not completely block water movement to and from these marshes (having some sort of bridge or culvert), they all restrict water and sediment movement compared to the natural hydrologic regime of the marsh. Ten of the potential barriers are on or cross ANP property or ANP conservation easements (table 2). If mitigation strategies for salt marsh migration are to be developed in the future, the sediment-supply and watersupply constrictions of these potential barriers should be taken into consideration.

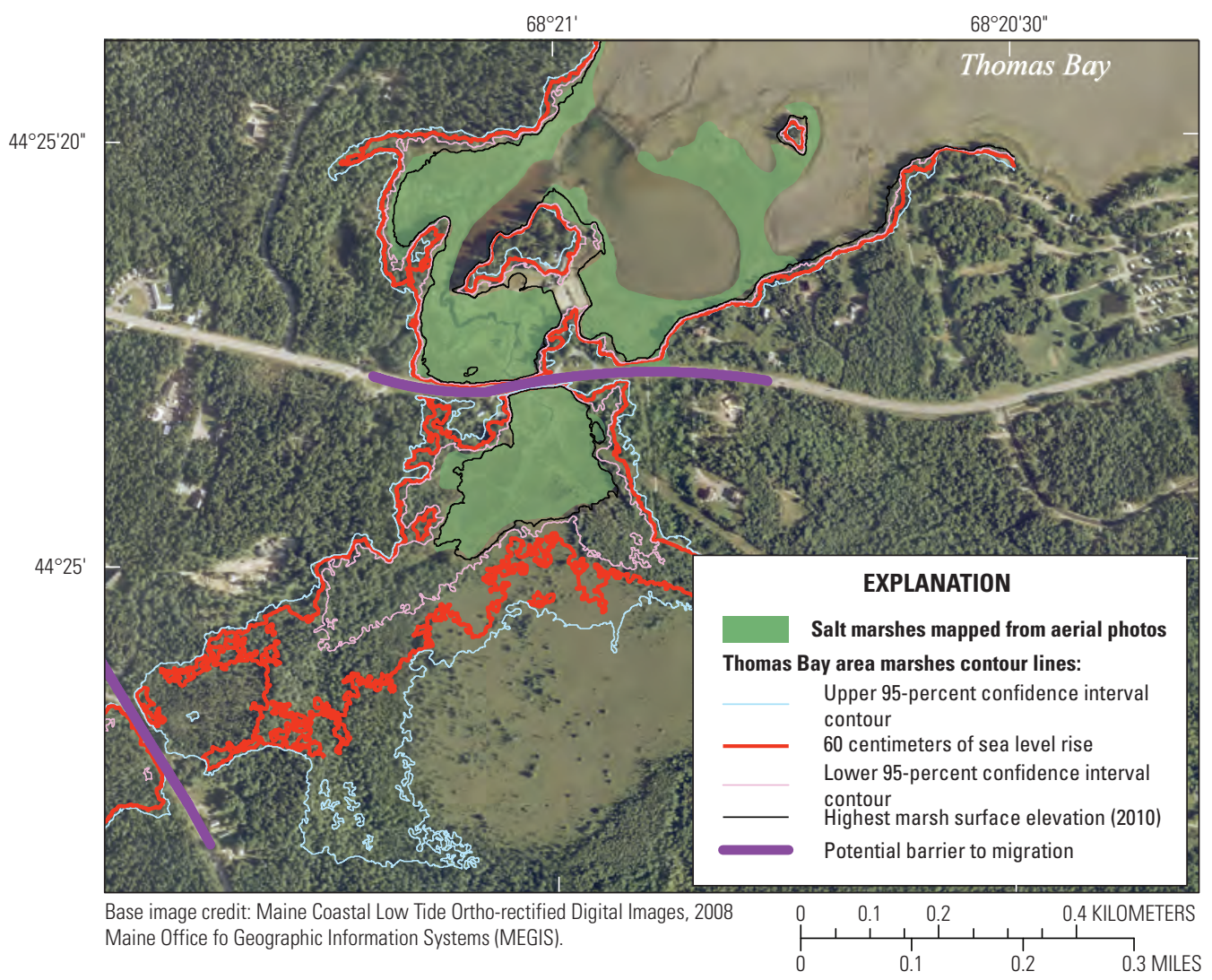

Figure 11. Static inundation map showing potential barriers to marsh migration for the Thomas Bay area, Bar Harbor, Maine. 
Table 2. Inventory of potential barriers to marsh migration in towns within the study area.

[ANP, Acadia National Park; --, none; Note: some of the salt marshes and potential barriers are located on the border between towns and appear more than once on the list.]

\begin{tabular}{lcc}
\hline \multicolumn{1}{c}{ Town } & $\begin{array}{c}\text { Number of } \\
\text { potential barriers }\end{array}$ & $\begin{array}{c}\text { Number of } \\
\text { potential barriers in ANP }\end{array}$ \\
\hline Bar Harbor & 8 & 2 \\
Brooklin & -- & -- \\
Brooksville & 3 & -- \\
Cranberry Isles & -- & -- \\
Deer Isle & 5 & -- \\
Franklin & 2 & -- \\
Frenchboro & -- & -- \\
Gouldsboro & 1 & -- \\
Hancock & 2 & -- \\
Lamoine & 4 & -- \\
Mount Desert & 2 & -- \\
North Haven & -- & -- \\
Penobscot & -- & -- \\
Sedgwick & -- & -- \\
Sorrento & -- & -- \\
Southwest Harbor & 2 & 2 \\
Stonington & 2 & -- \\
Surry & -- & -- \\
Swans Island & 2 & 1 \\
Tremont & 7 & 2 \\
Trenton & 2 & - \\
Winter Harbor & 2 & - \\
\hline & & - \\
\hline
\end{tabular}

\section{Summary and Conclusions}

Salt marshes provide significant ecological functions that include nursery and breeding habitat for fish, birds, and other wildlife species; organic-matter production; storm, flood, and erosion protection; carbon sequestration; and filtration of nutrients, sediments, and contaminants from waters entering the coastal zone. Salt marshes exist in a narrow elevation range relative to sea level; in general, the tidal range favorable to salt-marsh formation and growth is between mean sea level (MSL) and the highest annual tide (HAT). For this reason, rising sea levels threaten the persistence of coastal salt marshes. Sea level has been rising globally for the last 20,000 years and has risen from 0.6 to 2.5 millimeters per year $(\mathrm{mm} / \mathrm{yr})$ in New England during the last century. Sea level is expected to continue to rise as a result of melting glaciers and polar ice and thermal expansion of the ocean; the estimated rate of sea-level rise (SLR) is as much as $8.4 \mathrm{~mm} / \mathrm{yr}$ over the next century. Although there is great uncertainty in the precise amount of SLR expected over the next century, a 60 -centimeter ( $\mathrm{cm}$; 2 -foot) rise has been cited as the environmental planning target by the State of Maine.

In response to rising sea levels, the vertical accretion and horizontal migration of salt-marsh surfaces onto adjacent low-lying land will be important for the survival of salt marshes in the future. The U.S. Geological Survey (USGS), in cooperation with the National Park Service (NPS), began a study in 2010 to map lowland areas around salt marshes in and near ANP and its associated lands that would be inundated with a $60-\mathrm{cm}$ SLR and that could potentially provide areas into which salt marshes could migrate under favorable conditions. The goals of the inundation mapping project were to indicate the areal extent of static landward inundation around salt marshes expected from $60 \mathrm{~cm}$ of SLR, identify adjacent lowlying land that may provide area into which salt marshes could migrate, and identify potential artificial barriers to migration; these are critical parts of any proactive adaptation strategy for salt-marsh persistence.

This study made use of topographic data collected using aircraft-borne light detection and ranging (LiDAR) during October 2010 as part of a larger data-collection effort along the northeastern shoreline from Long Island, New York, to Eastport, Maine. The overall accuracy of the LiDAR data had a root mean square error (RMSE) of $11.3 \mathrm{~cm}$. This study also used digital color aerial photography from Eastern Penobscot Bay to Schoodic Point, taken during August 2008 at or near low-tide conditions and consisting of high-resolution 24-bit color orthorectified digital images with a pixel resolution of 0.5 meters (m); other high-resolution digital images, which are available online, also were used.

The study marshes consisted of 47 salt marshes previously mapped on and near ANP-associated lands and an additional 67 salt marshes identified from high-resolution aerial photos in an area from western Penobscot Bay east to Gouldsboro, Maine. The inventory of salt marshes in the study area indicates that marshes cover a total area of at least 340 ha (many of the very small salt marshes in the study area were not inventoried); the inventoried marshes range in size from 0.11 to 52 ha with a median size of about 1 ha. Only a very few, such as Grand Marsh in Gouldsboro, the marshes associated with the Northeast Creek estuary, Bass Harbor Marsh, and large series of marshes at the end of Hog Bay, north of Mount Desert Island, are larger than 10 ha. Most of the marshes identified in the inventory are fairly small, isolated marshes. Twenty-six of the 114 marshes are within ANP and easements held by the ANP, and one is owned by the State of Maine.

Elevation reference marks (ERMs) were established for vertical datum control for control-point surveys done for this study and to serve as stable datum points to support future salt-marsh research. The ERMs established for this study were documented and uploaded to the NPS Denver Service Center survey monuments database. Control points surveyed by the U.S. Geological Survey at selected salt marshes indicated that the LiDAR data used to delineate the marshes and the inundation contours had a RMSE of $13.3 \mathrm{~cm}$ in salt marsh 
habitats. This was used to calculate the 95-percent confidence interval to be $\pm 26 \mathrm{~cm}$, which was used to delineate confidence interval contours above and below the SLR contours.

The highest elevation at each salt marsh was selected as the common datum from which to delineate the inundation contours (as a proxy for the highest annual tide). A set of four contour lines were delineated for each marsh:

- contour lines representing HME

- the inundation contour line for $60 \mathrm{~cm}$ of SLR

- the contour line of the upper 95-percent confidence interval above the $60-\mathrm{cm}$ SLR line (SLR $+26 \mathrm{~cm})$

- the contour line of the lower 95-percent confidence interval below the $60-\mathrm{cm}$ SLR line (SLR $-26 \mathrm{~cm}$ )

In addition, any artificial structures presenting potential barriers to salt-marsh migration were delineated for each salt marsh in the study area. The differences in inundated areas between the $60-\mathrm{cm}$ SLR $+26 \mathrm{~cm}$ and $60-\mathrm{cm}$ SLR $-26 \mathrm{~cm}$ contour lines indicate the spatial representation of uncertainty associated with the topographic data used to produce the inundation contour lines. Inundation contour lines and HME contour lines, salt-marsh polygons, barriers to migration, ERMs, and surveyed control points for 114 salt marshes are stored in a geodatabase for use in a geographic information system. The geodatabase accompanies this report and is available for download at http://pubs.usgs.gov/sir/2012/5290/.

The amount of land that will be inundated with $60-\mathrm{cm}$ SLR was estimated to be approximately 350 ha in upland areas adjacent to the inventoried salt marshes, a large portion of which is currently (2012) freshwater wetland habitat. This total inundation area, however, is not evenly distributed across the study area. Only a few of the marshes have relatively large areas for possible migration (more than 200 percent of their size in 2010). While salt marshes in ANP account for 23 percent of all the marshes in the study, two large areas within ANP (Northeast Creek and Bass Harbor Marsh) account for 170 ha (50 percent) of the total amount expected to be inundated. Similarly, the average distance inland from the current marsh edge to the inundation contour in 75 percent of the marshes is only 20 meters or less. Fringing marshes in general have very little room for migration or expansion in their adjacent upland areas.

A total of 41 potential barriers to marsh migration were identified in and around the 110 salt marshes analyzed in the study area. While many of the potential barriers identified do not completely block water movement to and from these marshes (having some sort of bridge or culvert), they all restrict water and sediment movement compared to the natural hydrologic regime of the marsh. Ten of the potential barriers are on or cross ANP property or ANP conservation easements. If mitigation strategies for salt marsh migration are to be developed in the future, the sediment-supply and watersupply constrictions of these potential barriers should be taken into consideration.

\section{References Cited}

Bozek, C.M., and Burdick, D.M., 2005, Impacts of seawalls on saltmarsh plant communities in the Great Bay Estuary, New Hampshire, USA: Wetlands Ecology and Management, v. $13, \mathrm{p} 553-568$.

Brock, John, and Sallenger, A.H., 2001, Airborne topographic LiDAR mapping for coastal science and resource management: U.S. Geological Survey Open-File Report 01-46, 4 p.

Cahoon, D.R., Reed, D.J., Kolker, A.S., Brison, M.M., Stevenson, J.C., Riggs, S., Christian, R., Reyes, E., Voss, C., and Kunz, D., 2009, Coastal wetland sustainability, chap. 4 of Titus, J.G., Anderson, K.E., Cahoon, D.R., Gesch, D.B., Gill, S.K., Gutierrez, B.T., Thieler, E.R. and Williams, S.J., Coastal sensitivity to sea-level rise-A focus on the mid-Atlantic region, a report by the U.S. Climate Change Science Program and the Subcommittee on Global Change Research: U.S. Climate Change Science Program Synthesis and Assessment Product 4.1U.S. Environmental Protection Agency, chap. 4, p. 57-72.

Craft, Christopher, Clough, Jonathan, Ehman, Jeff, Joye, Samantha, Park, Richard, Pennings, Steve, Guo, Hongyu, and Machmuller, Megan, 2009, Forecasting the effects of accelerated sea-level rise on tidal marsh ecosystem services: Frontiers in Ecology and Environment, v. 7, no. 2, p. 73-78.

Day, J.W., Christian, R.R., Boesch, D.M., Yanez-Arancibia, A., Morris, J., Twilley, R.R., Naylor, L., Schaffner, L., and Stevenson, C., 2008, Consequences of climate change on the ecogeomorphology of coastal wetlands: Estuaries and Coasts, v. 31, p. 477-491.

Frumhoff, P.C., McCarthy, J.J., Melillo, J.M., Moser, S.C., Wuebbles, D.J., 2007, Confronting climate change in the U.S. northeast-Science, impacts, and solutions: Cambridge, Mass., Union of Concerned Scientists, 146 p.

Gesch, D.B., 2009, Analysis of LiDAR elevation data for improved identification and delineation of lands vulnerable to sea-level rise: Journal of Coastal Research, Special Issue Number 53, p. 49-58.

Gesch, D.B., Gutierrez, B.T., and Gill, S.K., 2009, Coastal elevations, in Titus, J.G., Anderson, K.E., Cahoon, D.R., Gesch, D.B., Gill, S.K., Gutierrez, B.T., Thieler, E.R. and Williams, S.J., 2009, Coastal sensitivity to sea-level rise: A focus on the Mid-Atlantic region, A report by the U.S. Climate Change Science Program and the Subcommittee on Global Change Research: Washington, D.C., U.S. Environmental Protection Agency, chap. 2, p. 25-42.

Goodman, J.E., Wood, M.E., and Gehrels, W.R., 2007, A 17 -year record of sediment accretion in the salt marshes of Maine (USA): Marine Geology, v. 242, p. 109-121. 
Kahl, J.S., Manski, D., Flora, M., and Houtman, N., 2000, Water resources management plan, Acadia National Park: Bar Harbor, Maine, National Park Service, NPS D-209, April 2000, 5 chap. [variously paged].

Kirshen, P., Watson, C., Douglas, E., Gontz, A., Lee, J., and Tian, Y., 2008, Coastal flooding in the Northeastern United States due to climate change: Mitigation and Adaptation Strategies for Global Change, v. 13, p. 437-451.

Kirwan, M.L., and Murray, A.B., 2008, Ecological and morphological response of brackish tidal marshland to the next century of sea level rise-Westham Island, British Columbia: Global and Planetary Change, v. 60, p. 471-486.

Lubinski, Sara, Hop, Kevin, and Gawler, Susan, 2003, U.S. Geological Survey-National Park Service Vegetation Mapping Program Acadia National Park, Maine: U.S. Geological Survey project report, revised edition-October 2003, 274 p., http://science.nature.nps.gov/im/units/netn/ inventory/docs/Inventory\%20Reports/acad_veg_report.pdf

Maine Department of Environmental Protection, 1993, Coastal sand dune rules - Chapter 355: Augusta, Maine, Maine Department of Environmental Protection, Bureau of Land and Water Quality, $21 \mathrm{p}$.

Maine Department of Environmental Protection, 2012, Highest annual tide (HAT) levels for year 2012-Maine coast from Eastport to Portsmouth, NH: Maine Department of Environmental Protection, accessed July 11, 2012, at http://www.maine.gov/dep/land/slz/predictions.pdf.

Maine Geolibrary, 2011, Web mapping services (WMS): Maine Geolibrary, accessed June 25, 2012, at http://www.maine.gov/geolib/wms.htm.

Maine Legislature, [undated]a, Natural resources protection act, secs. 480-A - 480Z of Protection and improvement of waters: Maine Legislature, accessed July 11, 2012, at http://www.mainelegislature.org/legis/statutes/38/ title38ch3.pdf.

Maine Legislature, [undated]b, Mandatory shoreland zoning act, secs. 435-449 of Protection and improvement of waters: Maine Legislature, accessed July 11, 2012, at http://www.mainelegislature.org/legis/statutes/38/ title38ch3.pdf.

McKee, K.L., and Patrick, W.H., Jr., 1988, The relationship of smooth cordgrass (Spartina altinerniflora) to tidal datums-A review: Estuaries, v. 11, no. 3, p. 143-151.
Morris, J.T., 2007, Ecological engineering in intertidal saltmarshes: Hydrobiologia, v. 557, p. 161-168.

National Digital Elevation Program, 2004, Guidelines for digital elevation data, version 1.0: U.S. Geological Survey, 93 p., http://www.ndep.gov/NDEP_Elevation_Guidelines_ Ver1_10May2004.pdf.

National Oceanic and Atmospheric Administration, 2000, Tidal datums and their applications: National Oceanic and Atmospheric Administration Special Publication NOS CO-OPS 1,112 p.

National Oceanic and Atmospheric Administration, 2012a, Continuously operating reference station (CORS): National Oceanic and Atmospheric Administration, accessed June 25, 2012, at http://www.ngs.noaa.gov/CORS/

National Oceanic and Atmospheric Administration, 2012b, OPUS - Online positioning user service: National Oceanic and Atmospheric Administration, accessed June 25, 2012, at http://www.ngs.noaa.gov/OPUS/about.jsp.

National Oceanic and Atmospheric Administration, 2012c, Vertical datum transformation: National Oceanic and Atmospheric Administration, accessed July 11, 2012, at http://vdatum.noaa.gov/welcome.html.

Poore, R.Z., Williams, R.S., Jr., and Tracey, Christopher, 2000, Sea level and climate: U.S. Geological Survey Fact Sheet 002-00, 2 p., accessed July 11, 2012, at http://pubs.usgs.gov/fs/fs2-00/.

Provost, M.W., 1976, Tidal datum planes circumscribing salt marshes: Bulletin of Marine Science, v. 26, no. 4, p. $558-563$.

Roman, C.T., Peck, J.A., Allen, J.R., King, J.W., and Appleby, P.G., 1997, Accretion of a New England (U.S.A.) salt marsh in response to inlet migration, storms, and sea-level rise: Estuarine, Coastal, and Shelf Science, v. 45, p. 717-727.

Slovinsky, P.A., and Dickinson, S.M., 2006, Impacts of future sea level rise on the coastal floodplain: Augusta, Maine, Maine Department of Conservation, Maine Geological Survey Open-File Report 06-14., 25 p.

Vaux, P.D., Nelson, S.J., Rajakaruna, N., Mittelhauser, G., Bell, K., Kopp, B., Peckenham, J., and Longsworth, G., 2008, Assessment of natural resource conditions in and adjacent to Acadia National Park, Maine: Fort Collins, Colo., National Park Service, Natural Resource Report NPS/NRPC/WRD/NRR-2008/069, 256 p 


\section{Appendix 1. Geospatial data of salt marshes, inundation contours, and surveying data in and near Acadia National Park, Maine.}

This section describes the geospatial data produced for this report. These geographic information system (GIS) layers were developed along with the report for the identification of areas adjacent to salt marshes that are expected to be inundated after 60 centimeters $(\mathrm{cm})$ of sea-level rise (SLR) occurs. The layers document the location and extent of the salt marshes, the extent of inundation expected around each marsh (with 95-percent confidence interval lines), potential manmade barriers to marsh migration, and all the surveying data collected as part of the project.

The layers are delivered in ESRI File Geodatabase format in the Universal Transverse Mercator, Zone 19, projection (in meters). Metadata are Federal Geographic Data Committee
(FGDC) compliant and provided in in Extensible Markup Language (xml) format.

The layers may be viewed in ArcGIS 9.x or ArcView 3.x or higher. If you do not have any GIS software, you may view the data via ArcReader, a free mapping application distributed by ESRI for Windows, Linux, and Unix operating systems at http://www.esri.com/software/arcgis/arcreader/download.html.

The data are available from the index page of this report (http://pubs.usgs.gov/sir/2012/5290/) and by searching for data at "ACAD" on the the National Park Service Integrated Resource Management Applications (IRMA) Web portal at https://irma.nps.gov/App/Portal/Home.

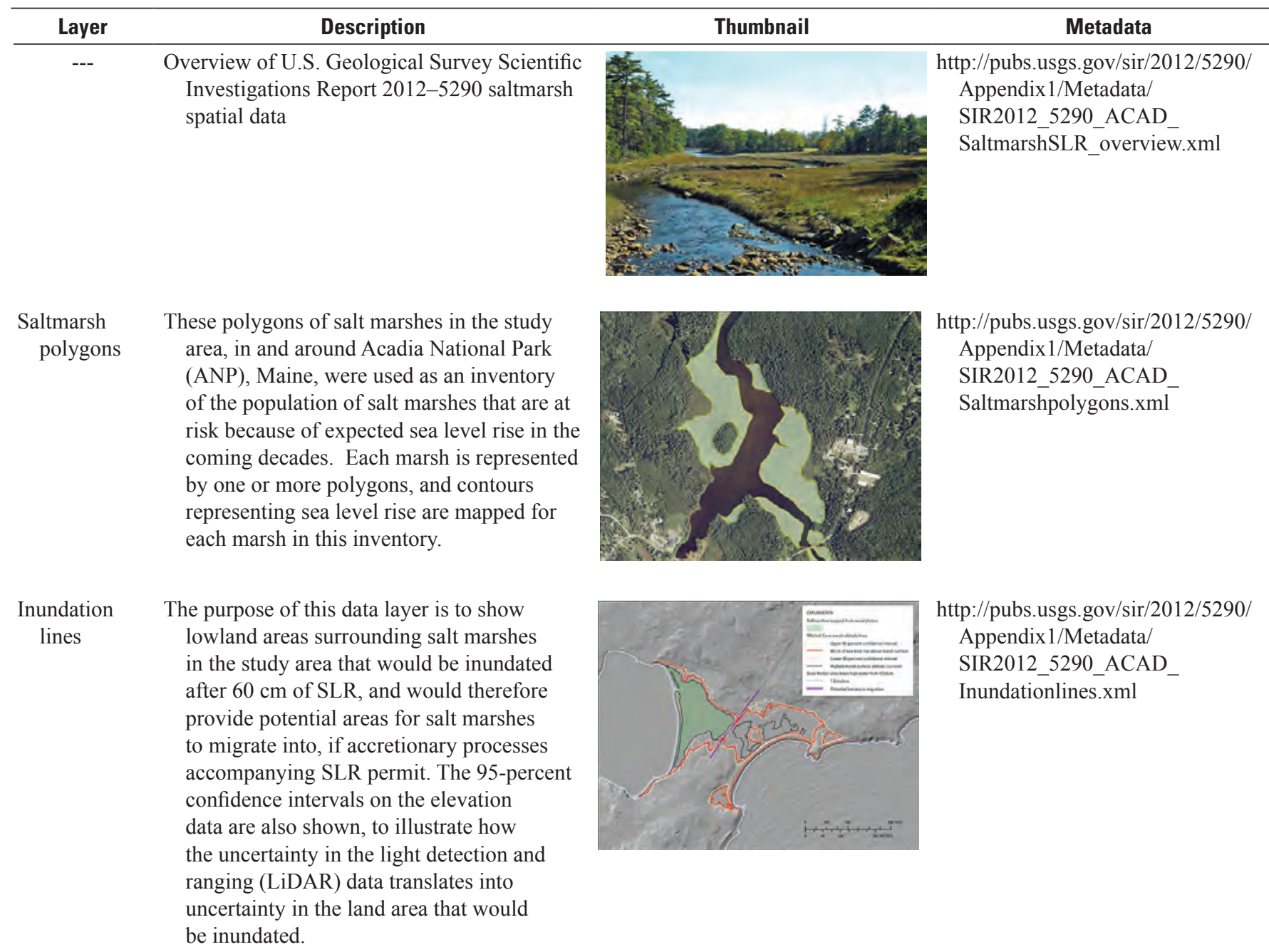




\begin{tabular}{|c|c|c|c|}
\hline Layer & Description & Thumbnail & Metadata \\
\hline $\begin{array}{l}\text { Potential } \\
\text { barriers to } \\
\text { migration }\end{array}$ & $\begin{array}{l}\text { Landforms that are potential barriers to the } \\
\text { horizontal migration of salt marshes in and } \\
\text { around Acadia National Park are potentially } \\
\text { important in the analysis of the future } \\
\text { viability of saltmarshes. Roads and railroad } \\
\text { grades both may act as potential barriers. } \\
\text { The potential barriers to migration of salt } \\
\text { marshes in and around ANP were developed } \\
\text { using the inundation lines for salt marshes } \\
\text { with } 60 \mathrm{~cm} \text { of sea level rise, and a shaded- } \\
\text { relief image of the LiDAR data on which } \\
\text { the inundation lines were based. }\end{array}$ & & $\begin{array}{l}\text { http://pubs.usgs.gov/sir/2012/5290/ } \\
\text { Appendix1/Metadata/ } \\
\text { SIR2012_5290_ACAD__ } \\
\text { Potentialbarriers.xml }\end{array}$ \\
\hline $\begin{array}{l}\text { Surveyed } \\
\text { benchmarks }\end{array}$ & $\begin{array}{l}\text { Published benchmarks and other base stations } \\
\text { used for differential Global Positioning } \\
\text { System (GPS) surveying of elevation } \\
\text { reference marks (ERMs) and marsh points. }\end{array}$ & & $\begin{array}{l}\text { http://pubs.usgs.gov/sir/2012/5290/ } \\
\text { Appendix1/Metadata/ } \\
\text { SIR2012_5290_ACAD_ } \\
\text { SurveyedBMs.xml }\end{array}$ \\
\hline $\begin{array}{c}\text { Surveyed } \\
\text { ERMs }\end{array}$ & $\begin{array}{l}\text { Vertical control was established using } \\
\text { previously-published benchmarks and } \\
\text { one base station that was not previously } \\
\text { published. ERM points were used as datum } \\
\text { to survey elevations of marsh points. }\end{array}$ & & $\begin{array}{l}\text { http://pubs.usgs.gov/sir/2012/5290/ } \\
\text { Appendix1/Metadata/ } \\
\text { SIR2012_5290_ACAD__ } \\
\text { SurveyedERMs.xml }\end{array}$ \\
\hline
\end{tabular}

Although these data have been used by the U.S. Geological Survey, no warranty expressed or implied is made by the U.S. Geological Survey as to the accuracy of the data. The act of distribution shall not constitute any such warranty, and no responsibility is assumed by the U.S. Geological Survey in the use of these data, software, or related materials. The use of firm, trade, or brand names in this report is for identification purposes only and does not constitute endorsement by the U.S. Geological Survey. The names mentioned in this document may be trademarks or registered trademarks of their respective trademark owners. 
Prepared by the Pembroke Publishing Service Center.

For more information concerning this report, contact:

Office Chief

U.S. Geological Survey

New England Water Science Center

Maine Office

196 Whitten Road

Augusta, ME 04330

dc_me@usgs.gov

or visit our Web site at:

http://me.water.usgs.gov 


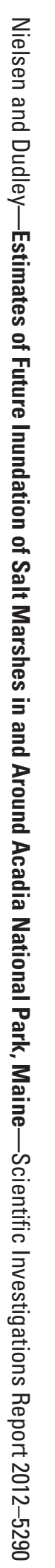

